GRI-94/0035

\title{
PIPELINE CORRIDORS THROUGH WETLANDS - \\ IMPACTS ON PLANT COMMUNITIES: NORRIS BROOK CROSSING, PEABODY, MASSACHUSETTS
}

\author{
TOPICAL REPORT \\ (August 1992-November 1993)
}

\author{
Prepared by \\ L.M. Shem, G.D. Van Dyke,* and R.E. Zimmerman \\ Center for Environmental Restoration Systems \\ Energy Systems Division \\ Argonne National Laboratory \\ 9700 South Cass Avenue \\ Argonne, Illinois 60439
}

\author{
For \\ GAS RESEARCH INSTITUTE \\ Contract No. 5088-252-1770 \\ GRI Project Manager \\ Ted Williams \\ Environment and Safety Research Group
}

December 1994

*Van Dyke is affiliated with the Department of Biology, Trinity Christian College, Palos Heights, Illinois. 
LEGAL NOTICE. This report was prepared by Argonne National Laboratory as an account of work sponsored by the Gas Research Institute (GRI). Neither GRI, members of GRI, nor any person acting on behalf of either:

a. Makes any warranty or representation, express or implied, with respect to the accuracy, completeness, or usefulness of the information contained in this report, or that the use of any apparatus, method, or process disclosed in this report may not infringe privately owned rights; or

b. Assumes any liability with respect to the use of, or for damages resulting from the use of, any information, apparatus, method, or process disclosed in this report. 


\section{DISCLAIMER}

This report was prepared as an account of work sponsored by an agency of the United States Government. Neither the United States Government nor any agency thereof, nor any of their employees, make any warranty, express or implied, or assumes any legal liability or responsibility for the accuracy, completeness, or usefulness of any information, apparatus, product, or process disclosed, or represents that its use would not infringe privately owned rights. Reference herein to any specific commercial product, process, or service by trade name, trademark, manufacturer, or otherwise does not necessarily constitute or imply its endorsement, recommendation, or favoring by the United States Government or any agency thereof. The views and opinions of authors expressed herein do not necessarily state or reflect those of the United States Government or any agency thereof. 


\section{DISCLAIMER}

Portions of this document may be illegible in electronic image products. Images are produced from the best available original document. 


\begin{tabular}{|c|c|c|}
\hline $\begin{array}{l}\text { REPORT DOCUMENTATION } \\
\text { PAGE }\end{array}$ & \begin{tabular}{l|l} 
7. REPORTNO. & GRI-94/0035 \\
\end{tabular} & 3. Reciplent's Accession No. \\
\hline \multirow{2}{*}{\multicolumn{2}{|c|}{$\begin{array}{l}\text { 4. Title and Subtitie } \\
\text { Pipeline Corridors through Wetlands - Impacts on Plant Communities: } \\
\text { Norris Brook Crossing, Peabody, Massachusetts }\end{array}$}} & 5. Report Date \\
\hline & & 6. December 1994 \\
\hline \multicolumn{2}{|c|}{$\begin{array}{l}\text { 7. Author(s) } \\
\text { L.M. Shem, G.D. Van Dyke, and R.E. Zimmerman }\end{array}$} & 8. Perrorming Organization Rept. No. \\
\hline \multicolumn{2}{|c|}{$\begin{array}{l}\text { 9. Performing Organization Name and Address } \\
\text { Center for Environmental Restoration Systems } \\
\text { Energy Systems Division } \\
\text { Argonne National Laboratory } \\
9700 \text { South Cass Avenue } \\
\text { Argonne, Ill. } 60439\end{array}$} & $\begin{array}{l}\text { 10. Project/TaskWork Unit No. } \\
\text { ACK } 85872 \\
\text { 11. Contract (c) or Grant (G) No. } \\
\text { (c) } 5088-252-1770 \\
\text { (G) }\end{array}$ \\
\hline \multicolumn{2}{|c|}{$\begin{array}{l}\text { 12. Sponsoring Organization Name andAddress } \\
\text { Environment and Safety Research Group } \\
\text { Gas Research Institute } \\
8600 \text { West Bryn Mawr Avenue } \\
\text { Chicago, Ill. } 60631\end{array}$} & $\begin{array}{l}\text { 13. Type of Report \& Perlod Covered } \\
\text { Topical Report } \\
\text { August } 1992 \text { - November } 1993\end{array}$ \\
\hline
\end{tabular}

15. Supplementary Notes

\section{Abstract (Limit 200 words)}

The goal of the Gas Research Institute Wetland Corridors Program is to document impacts of existing pipelines on the wetlands they traverse. To accomplish this goal, 12 existing wetland crossings were surveyed. These sites varied in elapsed time since pipeline construction, wetland type, pipeline installation techniques, and rightof-way (ROW) management practices. This report presents the results of a survey conducted August 17-19, 1992, at the Norris Brook crossing in the town of Peabody, Essex County, Massachusetts. The pipeline at this site was installed during September and October 1990. A backhoe was used to install the pipeline. The pipe was assembled on the adjacent upland and slid into the trench, after which the backhoe was used again to fill the trench and cover the pipeline. Within two years after pipeline construction, a dense vegetative community, composed predominantly of native perennial species, had become established on the ROW. Compared with adjacent natural areas undisturbed by pipeline installation, there was an increase in purple loosestrife and cattail within the ROW, while large woody species were excluded from the ROW. As a result of the ROW's presence, habitat diversity, edge-type habitat, and species diversity increased within the site. Crooked-stem aster, Aster prenanthoides (a species on the Massasschusetts list of plants of special concern), occurred in low numbers in the adjacent natural areas and had reinvaded the ROW in low numbers.

17. Document Analysis a. Descriptors

b. Identifiers/Open-Ended Terms

c. COSATI Field/Group

\begin{tabular}{|c|c|c|}
\hline $\begin{array}{l}\text { 18. Avaliability Statement } \\
\text { Release unlimited }\end{array}$ & $\begin{array}{l}\text { 19. Security Class (this Report) } \\
\text { Unclassified }\end{array}$ & 21. No. of Pages \\
\hline & $\begin{array}{c}\text { 20. Security Class (This Page) } \\
\text { Unclassified }\end{array}$ & 22. Price \\
\hline
\end{tabular}




\section{Research Summary}

Title Pipeline Corridors through Wetlands - Impacts on Plant Communities: Norris Brook Crossing, Peabody, Massachusetts

Contractor

Principal Investigators

Report Period

Objective

Technical Perspective
Argonne National Laboratory

L.M. Shem, G.D. Van Dyke, and R.E. Zimmerman

August 1992-November 1993

Document the historical impacts of pipeline rights-of-way (ROWs) on wetlands

The impact of pipeline construction in wetlands is a very sensitive issue and one that is under strict regulatory control. Neither the natural gas industry nor the regulatory community has a documented basis to define the type, value, or environmental consequences of past pipeline activities in wetlands. This report is one of a series documenting these impacts. This data report is the result of field studies of a two-year-old pipeline ROW through a scrub-shrub wetland, a common wetland type in the northeastern United States.

Results Observable impacts of the ROW on hydrology and vegetation were limited to the ROW itself. Modifications to the topography of the ROW consisted of a slight elevation of the soil surface at the center of the ROW and several shallow depressions on the side of the ROW where the excavated soil was stored. Although only 22 months had elapsed between final grading of the site following pipeline installation and sampling of the ROW, the ROW already supported a dense stand of herbaceous vegetation composed predominantly of native perennial species. Forty-three species were present in ROW plots compared to 67 species in plots in the adjacent natural areas (NAs). Species on the ROW had greater fidelity to wetlands than did the species in the natural communities adjacent to the ROW, as measured by two different indicator values. No shrubs, saplings, or trees were present in the ROW, so the habitat was different from that in the adjacent wetland. The presence of the ROW contributed to species diversity in the wetland. Two species, cattail and purple loosestrife, were more abundant in the ROW than in adjacent areas. Crooked-stem aster, a species of special concern in Massachusetts, was present in the ROW as well as in the NAs. Further studies are needed to determine the 
persistence of these species in the ROW and the rate of reinvasion by other species found in the adjacent NAs.

Technical Approach

A relatively homogeneous study site was selected within a scrubshrub community occupying about 200 meters along the ROW near the western edge of the wetland crossing. Data were collected on soils, hydrology, and plant cover from transect plots within both sides of the ROW and the NAs on either side of the ROW. Plant data were analyzed to determine similarities and differences between the two sides of the ROW and the two adjacent NAs.

Project Implications

This study shows that within two years after installation of the pipeline by open trenching, the ROW in this wetland community had developed a dense stand of mostly native plant species. There was no evidence of seeding, liming, or fertilization. General hydrology of the site appeared to be unaffected by the presence of the ROW. The ROW vegetation contributes to the species richness of the wetland and creates habitat diversity; however, it also creates an interruption in the natural plant community. One relatively rare species and two species considered undesirable occurred on the ROW.

Ted A. Williams

GRI Project Manager

Environment and Safety Research Group 


\section{Contents}

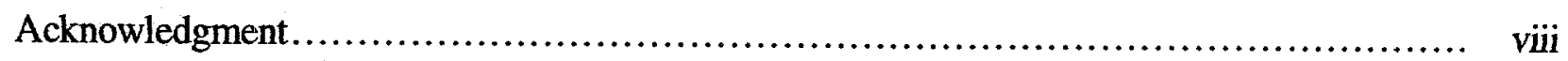

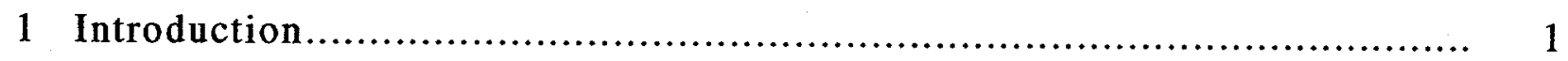

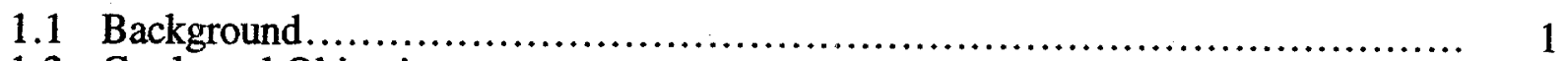

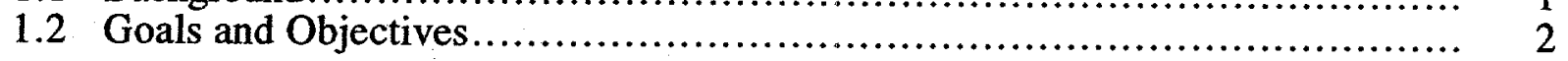

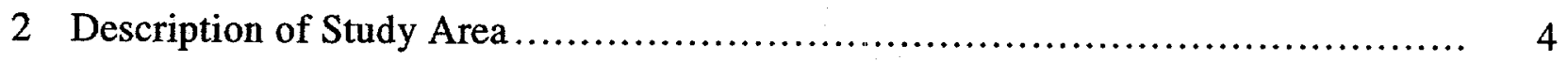

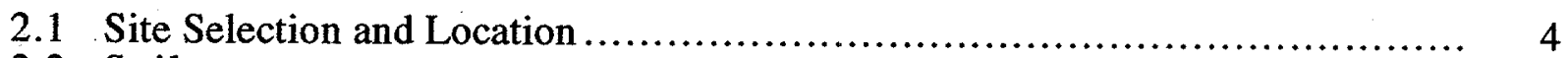

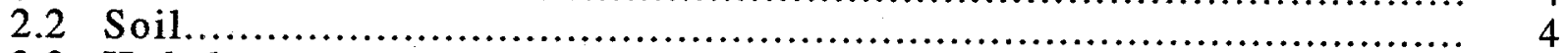

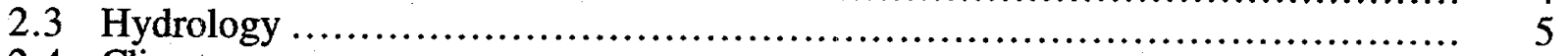

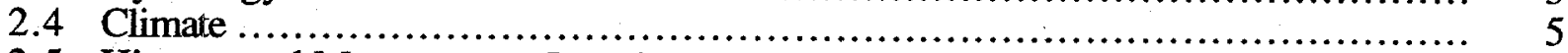

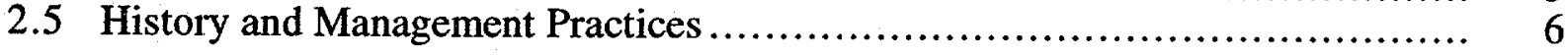

3 Approach and Methods ........................................................ 7

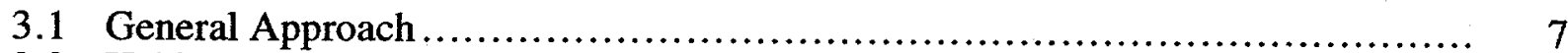

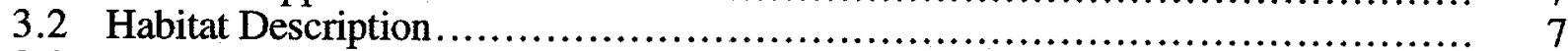

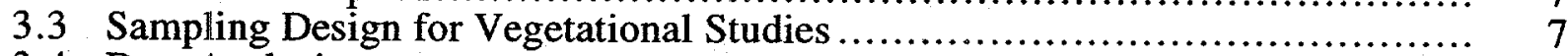

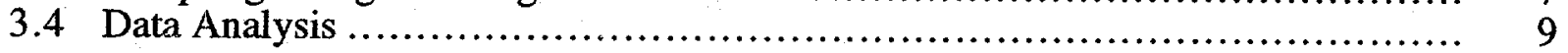

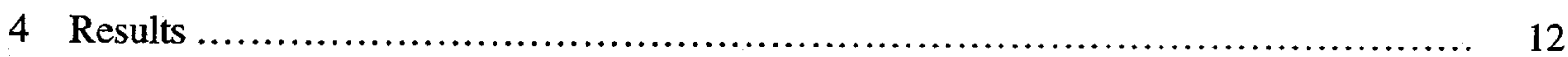

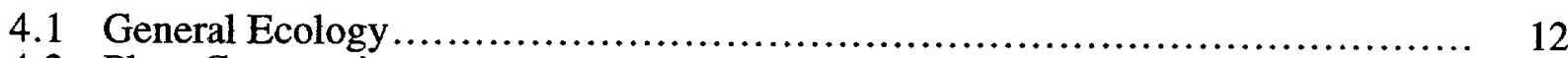

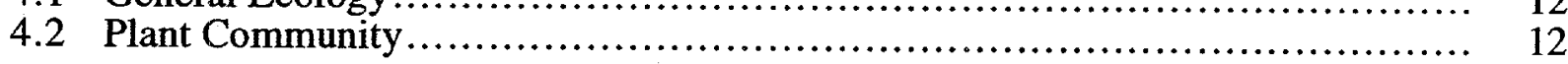

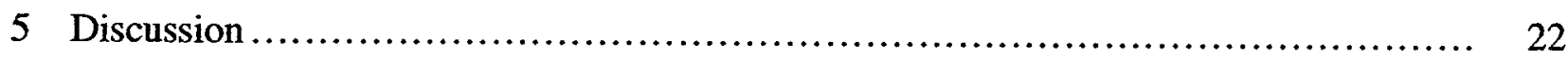

6 Summary and Conclusions..................................................... 24

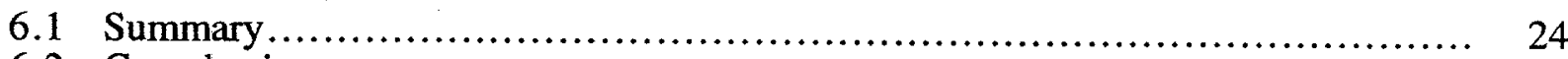

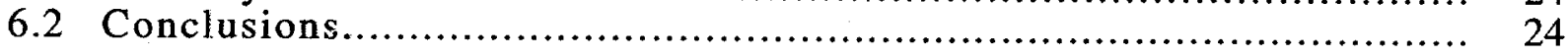

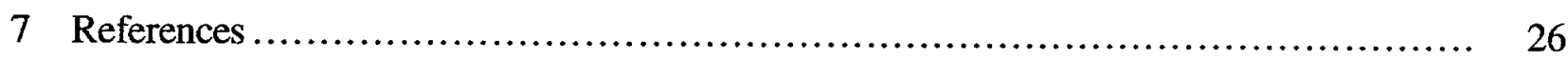

Appendix A: Definition of Jurisdictional Wetlands ................................ 27

Appendix B: Data Analysis - Definitions and Equations........................... 31

Appendix C: Plant Species List, Areal Coverage Data, and Species Distributions...... 37

\section{Figures}

1 Location of the Norris Brook Study Site in Peabody, Essex County, Massachusetts . 


\section{Figures (Cont.)}

2 Generalized Cross Section of the Norris Brook Study Site

Showing the ROW, Pipeline Location, and Vegetation Types

3 Plan View of the Norris Brook Study Site Showing Transect Length and Spacing..... 8

4 Location and Dimensions of Sampling Plots along One Transect ....................

$5 \quad$ Number of Species in Each Wetland Indicator Category by Area.................... 16

$6 \quad$ Percent of Species in Each Wetland Indicator Category by Area................... 17

A.1 Schematic Diagram of the Wetland Delineation Process................................. 30

Tables

1 Number of Plant Species by Wetland Indicator Category

Found in the Study Plots in the NAs and the ROW

2 Number of Plant Species by Wetland Indicator Category

Found in the Herb Stratum in the Study Plots in the

North ROW and the South ROW.

3 Number of Plant Species by Wetland Indicator Category

Found in the Study Plots in the NNA and SNA

4 Dominant Species by Vegetative Stratum for Each Area................................

5 Coefficient of Community Values Comparing Similarity of Species

Occurring in Study Plots

6 Prevalence Index and Average Wetland Values for All Species

and Dominant Species Found in the NAs and the ROW....

C.1 Plant Species List for Norris Brook Crossing

C.2 Percent Areal Coverage Estimates of Each Species by Stratum for Norris Brook Crossing

C.3 Average Percent Coverage, Absolute Frequencies, and Distribution of Species by Stratum for Norris Brook Crossing 


\section{Acknowledgment}

The authors would like to thank Kathleen A. Strakosch, The New York Natural Heritage Program, New York State Department of Environmental Conservation, Albany, New York, for verifying the identifications of the plant species found at the Norris Brook crossing site, Peabody, Massachusetts. 


\section{Pipeline Corridors through Wetlands - \\ Impacts on Plant Communities: Norris Brook Crossing, \\ Peabody, Massachusetts}

by

L.M. Shem, G.D. Van Dyke, and R.E. Zimmerman

\section{Introduction}

\subsection{Background}

Pipelines for the distribution of natural gas traverse all types of terrain, including wetlands. Prior to the wetlands regulatory climate of the late 1980s and the early 1990s, the construction of right-of-way (ROW) corridors through wetlands was often welcomed by landowners and local communities; ROW corridors opened up wetlands, thereby providing public access. With the promulgation of more stringent regulations related to development activities (including no-net-loss wetland policies), an assessment of the historical impacts of pipeline ROWs through wetlands is needed to evaluate construction and reclamation methods, assist in future permit application processes, and evaluate future construction costs.

The Gas Research Institute (GRI) Wetland Corridors Program was designed to evaluate impacts of gas-pipeline construction and subsequent maintenance on wetlands. The data gathered through this GRI program provide a better understanding of the type, degree, and duration of impacts of various pipeline-construction techniques. This information will enable the industry to evaluate current construction practices and provide factual input to regulatory bodies.

Careful evaluation of the impacts of pipeline installation on wetlands is necessary because specific impacts may be beneficial to some plant and/or animal species and detrimental to others. Some impacts may appear to be detrimental when, in fact, they improve conditions for certain sensitive species or provide for greater diversity of species and habitat.

The initial questions addressed by the GRI Wetland Corridors Program are as follows:

1. Do ROW construction and/or management practices lead to differences in ROW plant communities with respect to adjacent wetland communities?

2. Does the ROW alter the diversity of the adjacent wetland community? If so, how far do the impacts extend?

3. Does the ROW enhance species diversity of the wetland? 
4. Are there ROW construction and management practices that can enhance the positive contributions of ROWs to wetlands and minimize detrimental impacts?

Answers to these broad questions will provide information related to a number of more specific questions. Data on the type of plant communities that develop on ROWs in various wetlands when specific pipeline construction and management practices are utilized and comparison of the ROW plant communities with the plant communities in areas adjacent to the ROW will provide a basis for comparing environmental impacts of previous and current construction and management practices. Valuable data for such comparisons include numbers of plant species present, species that are dominant, percentage of the species that are native to the area, and fidelity of the plants to wetlands. Other measures of the quality of species present are also valuable, but those data are not available at present.

Concern exists as to whether pipeline corridors provide avenues of access for nonnative and invasive plants. Whether such plants become established along pipeline ROWs and from there invade adjacent areas, and the extent to which such invaders modify the plant communities in adjacent areas, are important to determining potential impacts of pipelines on wetlands.

Potential positive impacts are also important to assess. The degree to which ROWs provide habitat for rare or endangered species and other desirable species that are poorly represented in the adjacent areas is important information. Assessments of impacts of pipeline corridors on wetlands should also include the contribution of corridors to both plant and animal species diversity.

Answers to the above questions will assist the industry and regulatory agencies in evaluating current installation and management practices and making modifications that are beneficial to wetland quality enhancement.

\subsection{Goals and Objectives}

The goal of the GRI Wetland Corridors Program is to document impacts of existing pipelines on the wetlands they transverse. To accomplish this goal, 12 existing wetland crossings were surveyed. The sites evaluated differed in years since pipeline installation (ranging from 8 months to 31 years), wetland type, installation technology used, and management practices. Each wetland survey had the following specific objectives:

- Document vegetative communities existing in the ROW and in adjacent wetland communities;

- Evaluate similarities and differences between the plant communities in the ROW and in the adjacent wetland communities; 
- Document qualitative changes to the topography, soils, and hydrology attributable to ROW construction; and

- Identify impacts caused by ROW construction on rare, threatened, endangered, or sensitive species.

These individual wetland objectives were fulfilled by the collection and analysis of field data and the presentation of those data and their analysis in nine individual site reports. An upcoming summary report further synthesizes and interprets the data from all individual sites.

The following sections constitute a data report of a field survey conducted over the period of August 17-19, 1992, at a pipeline crossing of Norris Brook in the town of Peabody, Essex County, Massachusetts. The pipeline was installed approximately two years prior to this survey. 


\section{Description of Study Area}

\subsection{Site Selection and Location}

Personnel from a local gas pipeline company assisted a team from Argonne National Laboratory (ANL) in selecting areas classified as "Jurisdictional Wetlands" under Section 404 of the Clean Water Act. Several wetland segments were identified along the ROW of a 12-in.$(30-\mathrm{cm}-)^{*}$ diameter pipeline, which was approximately $2.5 \mathrm{mi}(4 \mathrm{~km})$ long, beginning in the town of Peabody and ending in the town of Danvers, Massachusetts. This pipeline had been installed during September and October 1990. Field visits were made to several of these wetland crossings. The pipeline crossing of Norris Brook within the town of Peabody was selected as a suitable study site. At this site, the wetland met the criteria of extending at least $200 \mathrm{~m}$ along the ROW and at least $50 \mathrm{~m}$ on each side of the ROW.

The natural vegetation along the ROW in this wetland consisted of two distinctive plant communities: (1) a scrub-shrub wetland (Cowardin et al. 1979) community, with scattered saplings and trees, which occupied the first $200 \mathrm{~m}$ of the row from the western edge of the wetland; and (2) an emergent marsh community, which extended to the eastern boundary of the wetland. A sampling site was selected within the scrub-shrub community. The location of the site in relationship to the town of Peabody is shown in Figure 1.

\subsection{Soil}

The soils at the site are mapped as Freetown soils (Soil Conservation Service [SCS] 1984). Freetown soils are classified as hydric soils (SCS 1991), which are deep, poorly drained soils found in depressions and on areas in uplands and outwash plains. Slopes range from 0 to $1 \%$. They are formed in highly decomposed organic material more than 51 in. $(130 \mathrm{~cm})$ thick and frequently contain woody fragments consisting of twigs, branches, logs, or stumps.

Areas with Freetown soils are typically associated with woodland production (SCS 1984), and Freetown soils support such trees as red maple, Atlantic white cedar, eastern hemlock, green ash, American elm, red spruce, and balsam fir.

\footnotetext{
* Measurements are given in metric units except where they were actually made in English units; in these cases, metric equivalents are given in parentheses.
} 


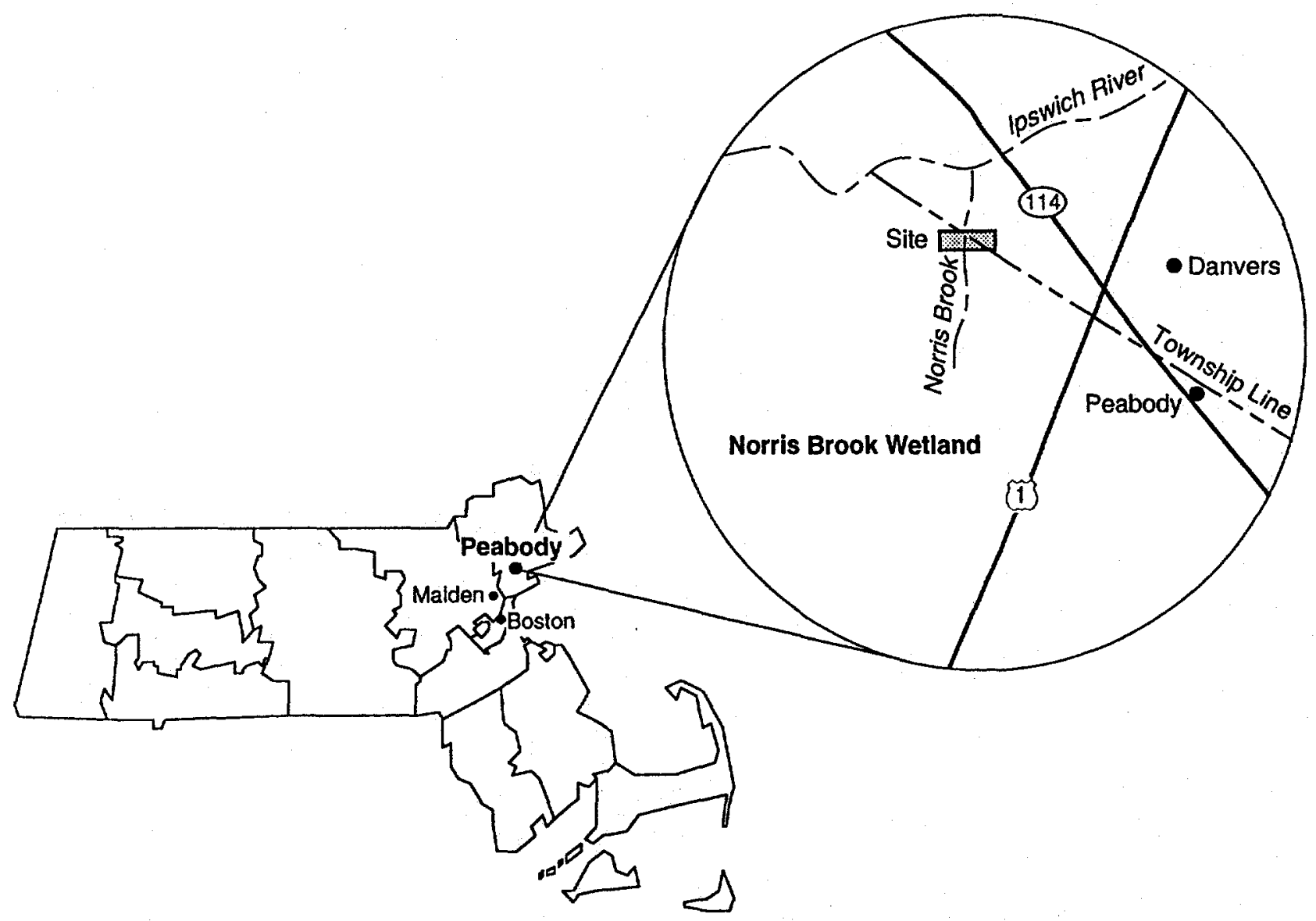

FIGURE 1 Location of the Norris Brook Study Site in Peabody, Essex County, Massachusetts

\subsection{Hydrology}

The Norris Brook study site is located on the floodplain of Norris Brook, approximately $0.3 \mathrm{mi}(0.48 \mathrm{~km})$ southwest of its confluence with the Ipswich River. At the study site, Norris Brook is a perennial stream with a broad valley. The stream, where it is crossed by the ROW, consists of a main channel and several smaller side channels within the peaty surface of the valley floor. The sides of the valley are steep, $8-15 \%$ grade, and consist of stony and gravelly soils. Because the pipeline crosses the valley at a slight angle, approximately $400 \mathrm{~m}$ of the ROW lies within the floodplain.

\subsection{Climate}

The Norris Brook site has a temperate climate (SCS 1984). The average summer temperature is $70^{\circ} \mathrm{F}\left(21^{\circ} \mathrm{C}\right)$, with an average daily maximum of $79^{\circ} \mathrm{F}\left(26^{\circ} \mathrm{C}\right)$. The average winter temperature is $28^{\circ} \mathrm{F}\left(-2^{\circ} \mathrm{C}\right)$, with an average daily minimum temperature of $19^{\circ} \mathrm{F}\left(-7^{\circ} \mathrm{C}\right)$. Total annual precipitation is $46 \mathrm{in}$. $(117 \mathrm{~cm}) ; 50 \%$ of the annual precipitation usually falls during April through September. Average seasonal snowfall is $58 \mathrm{in} .(147 \mathrm{~cm})$, and at least $1 \mathrm{in} .(2.5 \mathrm{~cm})$ of 
snow cover persists for 63 days per year, on average. The growing season for most crops is April through September.

\subsection{History and Management Practices}

Area History. Much of the area in the towns of Peabody and Danvers is developed residential and commercial zones. Adjacent to the Norris Brook floodplain, just northwest of the site, is an electrical power relay station. Gravel pits are beyond the station. The east bank of the Norris Brook floodplain, across from the site, is steep and has areas of forests and open meadows. Soil survey maps (SCS 1984) indicate that mining has taken place in the floodplain between the site and the Ipswich River. The western one-third of the floodplain along the ROW consists of scrub-shrub wetland with occasional saplings and trees, while the eastern two-thirds is emergent marsh.

Pipeline Construction. The pipeline was constructed across the Norris Brook floodplain during September and October 1990. It was constructed by clearing a ROW approximately $50 \mathrm{ft}(15 \mathrm{~m})$ wide and removing logs and brush. A backhoe that was operated from timber mats was used to dig the trench. The ditch was excavated to provide a minimum of 36 in. $(0.91 \mathrm{~m})$ of cover over the pipeline at final grading. Surface soils were stored on one side of the ditch, and subsoils were stored on the other side of the ditch. The pipeline was assembled on adjacent upland and pushed, pulled, and floated across the wetland in a single operation. After installation of the pipeline, the backhoe was used again to backfill the trench, return the topsoil, and restore the wetland to its original contour. All mats were removed from the wetland.

Postconstruction Maintenance. Construction plans called for seeding the wetland with a fast-growing annual grass - the expectation was that native wetland vegetation would soon replace this grass. If construction occurred in late fall, seeding was to be delayed until the following spring. Information was not available as to whether the ROW through the Norris Brook wetland had been seeded per the construction plans. ROW maintenance plans call for keeping the ROW free of large, woody vegetation. 


\section{Approach and Methods}

\subsection{General Approach}

The primary objectives listed in the Introduction (Section 1.2) provided the general guidelines for this study. To allow comparison of results across sites, methodologies for site reconnaissance, vegetation data collection, and data analysis used at this site were similar to those used at the other sites.

Vegetation sampling was designed to provide data for both the herb and the scrub-shrub strata.

\subsection{Habitat Description}

General data on the habitats of the site, including topography, water levels, direction of water flow, soil conditions, and structure of the plant communities, were recorded on the basis of the general reconnaissance of the site. Soil characteristics, as observed by means of a hand auger, were compared with those listed for Freetown soils (SCS 1984).

ROW boundaries were identified on the basis of construction plan information and field observations. Figure 2 shows a generalized cross-sectional profile of the Norris Brook site, including the $65-\mathrm{ft}-(20-\mathrm{m}-)$ wide ROW, the natural vegetation, and the pipeline location.

\subsection{Sampling Design for Vegetational Studies}

Four areas were defined on the basis of their relationship to the midline of the ROW. These four areas consist of the two sides of the ROW and the two adjacent natural areas (NAs), wetlands undisturbed by pipeline installation, on either side of the ROW. This definition of areas allows comparisons between the two vegetative communities in the NAs on either side of the ROW, the vegetative communities developing on the two sides of the ROW, and the vegetative communities developing on the ROW and those occurring in the NAs. For convenience, these four areas are designated at each site by the direction they lie from the midline of the ROW; that is, north and south NAs (NNA and SNA) and north and south sides of the ROW.

Transects. Within the scrub-shrub wetland, five transect starting points were established at $15-\mathrm{m}$ intervals along the midline of the ROW. Transects were established perpendicular to the midline of the ROW, extending $25 \mathrm{~m}$ in either direction from each transect starting point. Figure 3 illustrates the general layout of these transects. The transects are oriented north-south because the ROW is oriented east-west. 


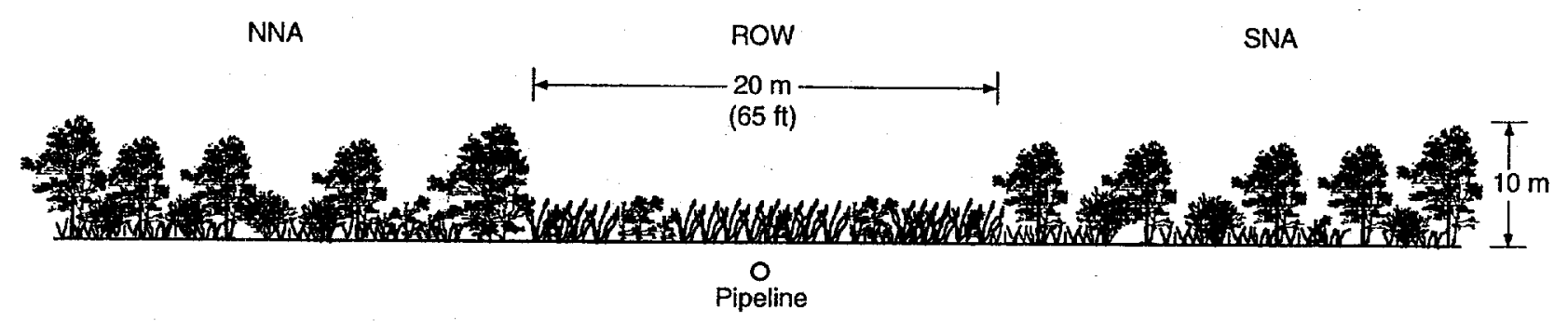

FIGURE 2 Generalized Cross Section of the Norris Brook Study Site Showing the ROW, Pipeline Location, and Vegetation Types

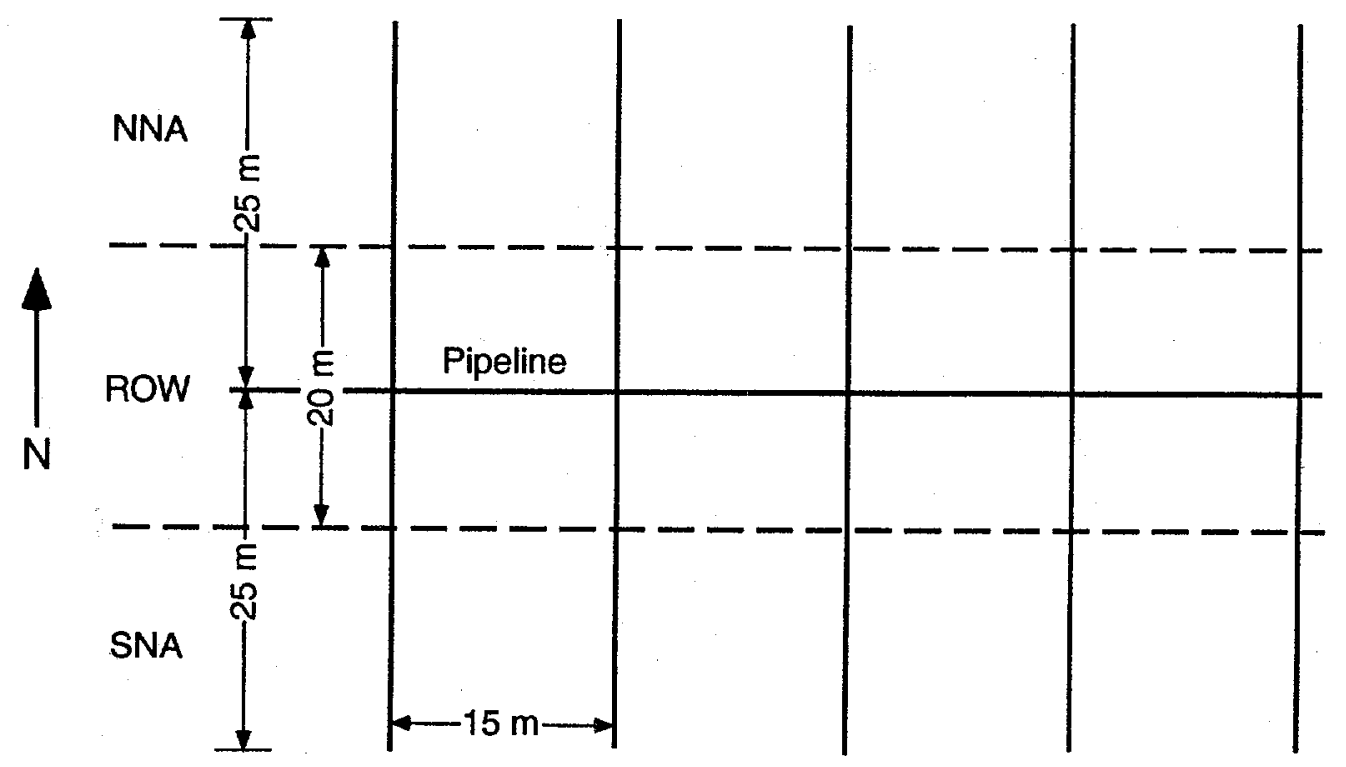

FIGURE 3 Plan View of the Norris Brook Study Site Showing Transect Length and Spacing

Four $2 \mathrm{~m} \times 5 \mathrm{~m}$ sampling plots were established along each transect for sampling the herb stratum. The two plots on the ROW began $2.5 \mathrm{~m}$ from the center of the ROW and extended to $7.5 \mathrm{~m}$ from the center of the ROW along the transect. The two plots in the NAs extended along the transects from 17.5 to $22.5 \mathrm{~m}$ from the center of the ROW. Shrub, vine, sapling, and tree data were collected in the NAs by using $10 \mathrm{~m} \times 10 \mathrm{~m}$ plots along each transect, beginning $15 \mathrm{~m}$ from the center of the ROW and extending to $25 \mathrm{~m}$ from the center of the ROW. Figure 4 illustrates the layout of plots along each transect in relationship to the pipeline and the edges of the ROW. All plots had the transect lines as their western edges.

Sampling Procedures. Vegetational data were collected for all plots at each site. Two specimens of each plant species, except rare or endangered species, found on or near the plots were collected as voucher specimens. Common names for the plants, wetland indicator categories, life-forms, and the origin of each species were derived from Reed (1988). 


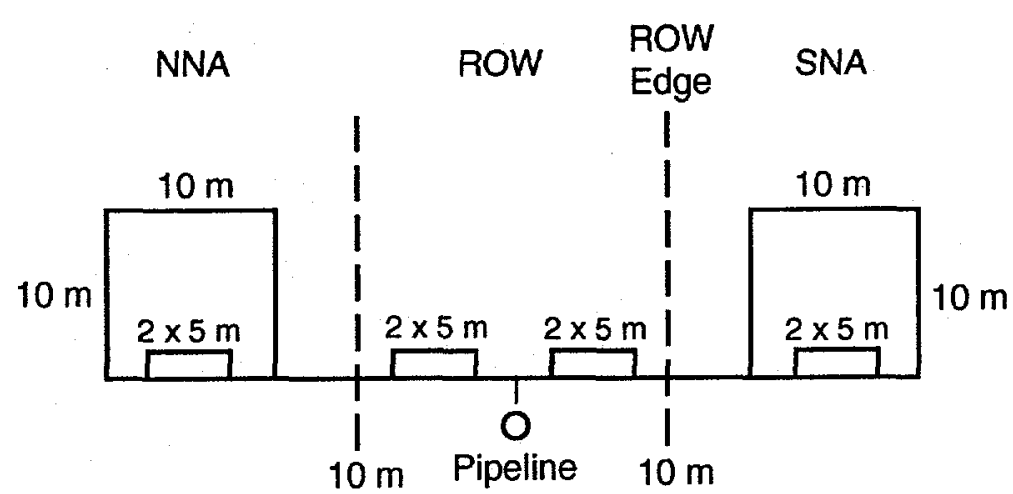

FIGURE 4 Location and Dimensions of Sampling Plots along One Transect

Vegetational data were collected by recording separate data for each species within the sampling plots. Visual estimates of areal cover were made separately for the herb, shrub, sapling, and tree strata. Definitions of strata are given in the Federal Manual for Identifying and Delineating Jurisdictional Wetlands (referred to as the Federal Manual) (FICWD 1989). The herb stratum is defined as herbaceous plants, including graminoids, forbs, ferns, herbaceous vines, and woody species under $3 \mathrm{ft}(0.91 \mathrm{~m})$ in height. The shrub stratum includes multistemmed, bushy shrubs and small trees and saplings between 3 and $20 \mathrm{ft}(0.91$ and $6.1 \mathrm{~m})$ in height. Saplings are defined as having a diameter at breast height (dbh) of 0.4 to 4.9 in. $(1.0$ to $12.4 \mathrm{~cm})$ and exceeding $20 \mathrm{ft}$ $(6.1 \mathrm{~m})$ in height. Trees are defined as having a dbh of greater than or equal to $5.0 \mathrm{in} .(12.7 \mathrm{~cm})$ and exceeding $20 \mathrm{ft}(6.1 \mathrm{~m})$ in height. No woody vines over $3 \mathrm{ft}(0.91 \mathrm{~m})$ tall were encountered. Estimates of surface area cover were also recorded for standing water.

\subsection{Data Analysis}

Analyses of vegetative data collected from sampling plots for all 17 sites studied as part of the GRI Wetland Corridors Program were consistent. Analyses focused on comparing the plant communities on the ROW with those in the NAs and determining hydrophytic characteristics of the plant communities in each area. Particular attention was given to dominant species because they are used in several wetland delineation methods. Although the number of species dominant, species richness, and the variety of plant life-forms present are all aspects of community diversity, no diversity indices were calculated. Diversity indices that use coverage values as measures of species importance were considered, but they were judged inappropriate because of differences in the number of strata in the ROW and NAs for the sites included in the Wetland Corridors Program and because coverage values are not additive across strata.

Species Richness, Wetland Indicator Categories, and Species Characteristics. The total number of species present (species richness) was determined for each side of the ROW, for the total ROW, for each NA, and for the NAs combined. Wetland indicator categories (Reed 1988) were identified for each species in the study plots. These categories are defined in Appendix B, Section B.1. The number of species in each category was determined for each area 
by stratum and for all strata combined. Because one plant species could occur in any or all strata, when data from different strata were combined, each species was considered only once, independent of the number of strata in which it occurred. Species characteristics, including lifeforms and origins, were also determined from Reed (1988). Symbols for life-forms and species origins are given in Appendix B, Section B.2.

Dominant Species. The definition of and methodology for the determination of dominant species in this study were taken from the 1989 Federal Manual (FICWD 1989). In the manual, dominance refers "strictly to the spatial extent of a species that is directly discernible or measurable in the field," as opposed to number of individuals present. Using this definition, dominant species were identified by plant stratum, rather than by total community. For each area, the dominant species were determined for each stratum by ranking each species in a plant stratum in descending order relative to total areal coverage of all plants in that stratum. The highest ranking species, which make up $50 \%$ of the total areal coverage or half of the total relative percent coverage (RPC), are the dominant species for that stratum. Any remaining species with $20 \%$ or more RPC are also considered dominant.

Community Similarity Indices. Sørensen's coefficient of community index $\left(\mathrm{CC}_{\mathrm{s}}\right)$ was used to measure similarity between vegetative communities (Brower, Zar, and von Ende 1990). This index uses the following formula:

$$
\mathrm{CC}_{\mathrm{s}}=2 \mathrm{c} /(\mathrm{a}+\mathrm{b})
$$

where
$a=$ the number of species in community $A$,
$b=$ the number of species in community $B$, and
$\mathrm{c}=$ the number of species in common between communities $\mathrm{A}$ and $\mathrm{B}$.

A $\mathrm{CC}_{\mathrm{s}}$ value of 1.00 indicates $100 \%$ similarity in species composition between communities $\mathrm{A}$ and $\mathrm{B}$. A value of 0.00 represents no species in common. Community similarity indices that use coverage values as measures of species importance were considered, but they were judged inappropriate because of differences in the strata present in the plant communities on the ROW compared to those in the NAs and because of the nonadditive characteristic of coverage data.

Comparisons were made between the combined ROWs and combined NAs, the two portions of the ROW, each portion of the ROW and its adjacent NA, and the two NAs.

Prevalence Index Values. Prevalence index values (PIVs) were calculated according to methods outlined in the 1989 Federal Manual (FICWD 1989), substituting RPC data from quadrat 
coverage estimates for relative frequencies from intercept data. This substitution is logical because both relative frequency and RPC are estimates of relative coverage (Bonham 1989). The PIV is an average wetland indicator value ranging from 1.0 to 5.0 and weighted by the RPC. Because areal coverage was determined by stratum, the PIVs were calculated for each area by stratum only. The average RPCs for each species in the five plots in each area were used in calculating the PIV for the area. The equation for calculating a PIV is presented in Appendix B, Section B.3.

Average Wetland Values. Average wetland values (AWVs) (Zimmerman et al. 1991) were calculated for the species in each of the five areas. This index is an average of the wetland indicator values for all plants present. It differs from the PIV in that it is not weighted by RPC; rather, all plants present are represented equally, regardless of their frequency of occurrence. Because areal coverage is not considered, the calculation of an index value is not restricted to one vegetative stratum. An overall site AWV was determined, as well as values for each stratum. See Appendix B, Section B.4, for the equation. 


\section{Results}

Observations made on the basis of the general site reconnaissance are summarized in Section 4.1. Vegetative data from plot sampling and the analysis of those data are discussed in Section 4.2 .

\subsection{General Ecology}

The study site was located on the western portion of the floodplain of Norris Brook. The site began $15 \mathrm{~m}$ east of the west bank and extended eastward for $75 \mathrm{~m}$. The vegetation within the study site was a scrub-shrub wetland community with a well-developed herb stratum. Saplings and small trees of red maple (Acer rubrum), silver maple (Acer saccharinum), and hybrids between these two species were also present. Because of the variation in silver maples and the continuum in variation between the hybrids and silver maples, no distinction was made between the hybrids and silver maples. The scrub-shrub community covered approximately the western third of the floodplain along the ROW. The area to the east of the study site along the ROW was an emergent marsh of sedges and cattails with scattered areas of open water.

The NAs adjacent to the ROW and undisturbed by pipeline installation were relatively level; there were only small hummocks at the bases of larger shrubs and trees, and those were formed by tussock-forming sedges and shallow channels in which water flowed. Within the ROW, the general elevation of the substrate over the pipeline was slightly higher than the average elevation of the area, and there were depressions near the north edge of the ROW, apparently created when excavated materials were reclaimed for ditch filling. Several small, shallow stream channels crossed the pipeline almost perpendicular to the ROW, flowing in a northerly direction. Alterations in topography were sufficiently minor that all plots, both in the NAs and on the ROW, had 100\% of the soil surface covered with water, which ranged in depth from $4 \mathrm{in}$. $(10 \mathrm{~cm})$ to $30 \mathrm{in}$. $(76 \mathrm{~cm})$. Several of the deeper depressions on the ROW resulted in small areas, generally less than $1 \mathrm{~m}^{2}$, devoid of emergent vegetation. None of these depressions, which generally occurred near the edge of the ROW, fell within the sampling plots. At the time of sampling, much of the ROW surface was vegetated with a dense cover of mostly native wetland perennials. Cores taken with a hand auger revealed a dark mucky soil, consistent in profile with the general description for Freetown muck.

\subsection{Plant Community}

Appendix $\mathrm{C}$ presents field data on the vegetative communities in the ROW and in the adjacent NAs. Table C. 1 lists plants found in this site by scientific names and authorities and gives common names, wetland indicator categories, life-forms, and origins, as determined from Reed (1988). Table C. 2 is a compilation of field plot data, listing the percentage areal cover for each species occurring within each sampling plot. Table C.3 summarizes the distribution of each 
species by average percent areal cover and plot frequency. Species are grouped according to the areas in which they were found.

Plant Species, Life-Forms, and Species Origins. Ninety species of vascular plants were collected from the Norris Brook site. These 90 species consisted of 5 species of ferns, 13 species of sedges and rushes, 5 species of grasses, 43 species of forbs, 15 species of shrubs, 2 species of woody vines, and 7 species of trees by life-form, as categorized in the National List (Reed 1988). Of the forbs, broad water-weed (Elodea canadensis) is a submerged macrophyte, common duckweed (Lemna minor) is a floating plant, and 11 species are emergents. Of the 13 species of sedges and rushes, 12 are emergents. One oak seedling (Quercus sp.) could not be identified to species. A small amount of moss was found in one plot. Ten species, including 4 species of sedges and rushes, 4 species of forbs, 1 species of woody vine, and 1 species of shrub, did not occur in the sampling plots. Further data analysis is based on the 80 species that occurred within the sampling plots.

Six of the species were introduced - two forbs, one grass, one shrub, one woody vine, and one tree. The introduced shrub, woody vine, and tree species occurred only in the NAs, the two introduced forb species occurred in both the NAs and the ROW, and the introduced grass species was limited to the ROW. All of the introduced species were perennials. Seven species, two of which did not occur in plots, have an annual growth form only. Four of the five annuals that did occur in plots occurred in the ROW and in the NAs, while one was limited to the NAs.

Fifty-nine of the species occurred within the sampling plots in the NAs. All strata were represented; however, few species were present in the sapling stratum, and only one species in the tree stratum was present. One species, crooked-stem aster (Aster prenanthoides), which occurred in low numbers in both the ROW and the NA, is listed as a species of special concern by the Massachusetts Endangered Species Act, Regulation 321 CMR 10.60 (State of Massachusetts 1990). This listing indicates that it is a species "which has been documented by biological research and inventory to have suffered a decline that could threaten the species if allowed to continue unchecked or that occurs in such small numbers or with such a restricted distribution or specialized habitat requirements that it could easily become threatened within Massachusetts."

Plots sampled in the ROW contained a total of 43 species, 30 of which also occurred in plots in the adjacent NAs. Only three species of shrubs - swamp rose, common winterberry (Ilex. verticillata), and silky dogwood (Cornus amomum) - had reinvaded the ROW, and all three species were present in low numbers. No tree or woody vine species were present on the ROW.

The sum of average coverages for individual species in the ROW was $190.9 \%$, indicating a relatively dense herb stratum. The sum of individual species coverages for all strata combined for the NAs was $253.2 \%$, and the sum of average coverages for all species in the herb stratum was $157.7 \%$. 
Species Richness and Wetland Indicator Categories. Table 1 lists the number of plant species found in the two NAs combined and the two sides of the ROW combined. Numbers of species are listed by wetland indicator category for each vegetative stratum. Although the same species may occur in more than one stratum, such species are counted only once when strata are combined. Definitions of strata were provided in Section 3.3 of this report.

Table 1 lists the total number of species found in each of the two habitat types (columns 3 and 4), as well as the number of species found in both habitats (column 5). The number of species that occurred in one habitat but not in the other are also listed (columns 6 and 7). Of the species occurring in sampling plots, $38 \%$ occurred in plots in both the NAs and the ROW, while $46 \%$ of the species were unique to the NAs and $16 \%$ were unique to the ROW.

Of the 43 species occurring in ROW plots, $95 \%$ were either OBL (53\%) or FACW (42\%); the remaining $5 \%$ were FAC. No FACU or UPL species were present on the ROW. Of the 67 species present in the NA plots, $76 \%$ were OBL $(36 \%)$ or FACW $(40 \%)$, while $15 \%$ were FAC, 3\% were FACU, and $4.5 \%$ were UPL. One taxon could not be identified to species. Three UPL and two FACU species were found in plots in the NAs, but no UPL or FACU species were present in the ROW plots. One of the species classified as an UPL species was Gronova's dodder (Cuscuta gronovii), a parasitic species that is probably not habitat-specific. However, according to Reed (1988), any species not listed should be counted as an upland species, and Gronova's dodder is not listed as a species occurring in wetlands. Another UPL species, common buckthorn (Rhamnus catharticus), is almost ubiquitous. The third UPL species was a perennial native forb, gray goldenrod (Solidago nemoralis). The two FACU species were poison ivy (Toxicodendron radicans) and Allegheny blackberry (Rubus allegheniensis), both woody species that are widely distributed.

Figure 5 shows a graphic comparison between the vegetation in the NAs and that on the ROW (the data are plotted by numbers of species in each wetland indicator category). Figure 6 shows a similar comparison, but plotted on the basis of the percent of species in each wetland indicator category. The percent of species in the more hydric categories, OBL and FACW, is higher for the ROW than for the NAs, while the percent of species in the more mesic categories, FACU and UPL, is lower for the ROW than for the NAs.

Table 2 indicates the distribution of plants in the plots on the north and south sides of the ROW. Of the 43 species occurring in ROW plots, $58 \%$ were found on both sides of the ROW, $32 \%$ were unique to the north side of the ROW (where the surface was much more uneven as a result of construction activity), and only $10 \%$ were unique to the south side of the ROW. The two FAC species occurring on the ROW were found exclusively on the north side.

Table 3, which is comparable with Tables 1 and 2, indicates the distribution of plants in the plots in the NNA and SNA. Of the 67 species occurring in NAs, $42 \%$ were common to both. Eighty-eight percent of the species were present in the herb stratum. Of the 67 species, $76 \%$ were OBL $(36 \%)$ or FACW (40\%), 15\% were FAC, and $7 \%$ were FACU (3\%) and UPL (4\%). The 
TABLE 1 Number of Plant Species by Wetland Indicator Category Found in the Study Plots in the NAs and the ROW (by individual stratum and combined strata)

\begin{tabular}{|c|c|c|c|c|c|c|c|}
\hline \multirow[b]{2}{*}{ Stratum } & \multirow[b]{2}{*}{$\begin{array}{l}\text { Wetland } \\
\text { Indicator } \\
\text { Categorya }\end{array}$} & \multicolumn{6}{|c|}{ Number of Species } \\
\hline & & $\begin{array}{l}\text { Occurring } \\
\text { in } \\
\text { NAs }\end{array}$ & $\begin{array}{c}\text { Occurring } \\
\text { in } \\
\text { ROW }\end{array}$ & $\begin{array}{l}\text { Common } \\
\text { to Both } \\
\text { Areas }\end{array}$ & $\begin{array}{c}\text { Unique } \\
\text { to } \\
\text { NAs }\end{array}$ & $\begin{array}{l}\text { Unique } \\
\text { to } \\
\text { Row }\end{array}$ & Total \\
\hline Herb & $\begin{array}{l}\text { OBL } \\
\text { FACW } \\
\text { FAC } \\
\text { FACU } \\
\text { UPL } \\
\text { Unidb } \\
\text { Total }\end{array}$ & $\begin{array}{r}22 \\
24 \\
8 \\
2 \\
2 \\
1 \\
59\end{array}$ & $\begin{array}{r}23 \\
18 \\
2 \\
0 \\
0 \\
0 \\
43\end{array}$ & $\begin{array}{r}14 \\
14 \\
2 \\
0 \\
0 \\
0 \\
30\end{array}$ & $\begin{array}{r}8 \\
10 \\
6 \\
2 \\
2 \\
1 \\
29\end{array}$ & $\begin{array}{r}9 \\
4 \\
0 \\
0 \\
0 \\
0 \\
13\end{array}$ & $\begin{array}{r}31 \\
28 \\
8 \\
2 \\
2 \\
1 \\
72\end{array}$ \\
\hline Shrub & $\begin{array}{l}\text { OBL } \\
\text { FACW } \\
\text { FAC } \\
\text { FACU } \\
\text { UPL } \\
\text { Unid } \\
\text { Total }\end{array}$ & $\begin{array}{r}5 \\
10 \\
4 \\
0 \\
1 \\
0 \\
20\end{array}$ & $\begin{array}{l}0 \\
0 \\
0 \\
0 \\
0 \\
0 \\
0\end{array}$ & $\begin{array}{l}0 \\
0 \\
0 \\
0 \\
0 \\
0 \\
0\end{array}$ & $\begin{array}{r}5 \\
10 \\
4 \\
0 \\
1 \\
0 \\
20\end{array}$ & $\begin{array}{l}0 \\
0 \\
0 \\
0 \\
0 \\
0 \\
0\end{array}$ & $\begin{array}{r}5 \\
10 \\
4 \\
0 \\
1 \\
0 \\
20\end{array}$ \\
\hline Sapling & $\begin{array}{l}\text { OBL } \\
\text { FACW } \\
\text { FAC } \\
\text { FACU } \\
\text { UPL } \\
\text { Unid } \\
\text { Total }\end{array}$ & $\begin{array}{l}0 \\
1 \\
1 \\
0 \\
0 \\
0 \\
2\end{array}$ & $\begin{array}{l}0 \\
0 \\
0 \\
0 \\
0 \\
0 \\
0\end{array}$ & $\begin{array}{l}0 \\
0 \\
0 \\
0 \\
0 \\
0 \\
0\end{array}$ & $\begin{array}{l}0 \\
1 \\
1 \\
0 \\
0 \\
0 \\
2\end{array}$ & $\begin{array}{l}0 \\
0 \\
0 \\
0 \\
0 \\
0 \\
0\end{array}$ & $\begin{array}{l}0 \\
1 \\
1 \\
0 \\
0 \\
0 \\
2\end{array}$ \\
\hline Tree & $\begin{array}{l}\text { OBL } \\
\text { FACW } \\
\text { FAC } \\
\text { FACU } \\
\text { UPL } \\
\text { Unid } \\
\text { Total }\end{array}$ & $\begin{array}{l}0 \\
1 \\
0 \\
0 \\
0 \\
0 \\
1\end{array}$ & $\begin{array}{l}0 \\
0 \\
0 \\
0 \\
0 \\
0 \\
0\end{array}$ & $\begin{array}{l}0 \\
0 \\
0 \\
0 \\
0 \\
0 \\
0\end{array}$ & $\begin{array}{l}0 \\
1 \\
0 \\
0 \\
0 \\
0 \\
1\end{array}$ & $\begin{array}{l}0 \\
0 \\
0 \\
0 \\
0 \\
0 \\
0\end{array}$ & $\begin{array}{l}0 \\
1 \\
0 \\
0 \\
0 \\
0 \\
1\end{array}$ \\
\hline $\begin{array}{l}\text { Combined } \\
\text { strata }\end{array}$ & $\begin{array}{l}\text { OBL } \\
\text { FACW } \\
\text { FAC } \\
\text { FACU } \\
\text { UPL } \\
\text { Unid } \\
\text { Total }\end{array}$ & $\begin{array}{r}24 \\
27 \\
10 \\
2 \\
3 \\
1 \\
67\end{array}$ & $\begin{array}{r}23 \\
18 \\
2 \\
0 \\
0 \\
0 \\
43\end{array}$ & $\begin{array}{r}14 \\
14 \\
2 \\
0 \\
0 \\
0 \\
30\end{array}$ & $\begin{array}{r}10 \\
13 \\
8 \\
2 \\
3 \\
1 \\
37\end{array}$ & $\begin{array}{r}9 \\
4 \\
0 \\
0 \\
0 \\
0 \\
13\end{array}$ & $\begin{array}{r}33 \\
31 \\
10 \\
2 \\
3 \\
1 \\
80\end{array}$ \\
\hline
\end{tabular}

a $\mathrm{OBL}=$ obligate wetland species; $F A C W=$ facultative wetland species; $F A C=$ facultative species; $F A C U=$ facultative upland species; and UPL = upland species. See Appendix $B$ for more detailed information on wetland indicator categories.

b Unid = plants not identified to species. 


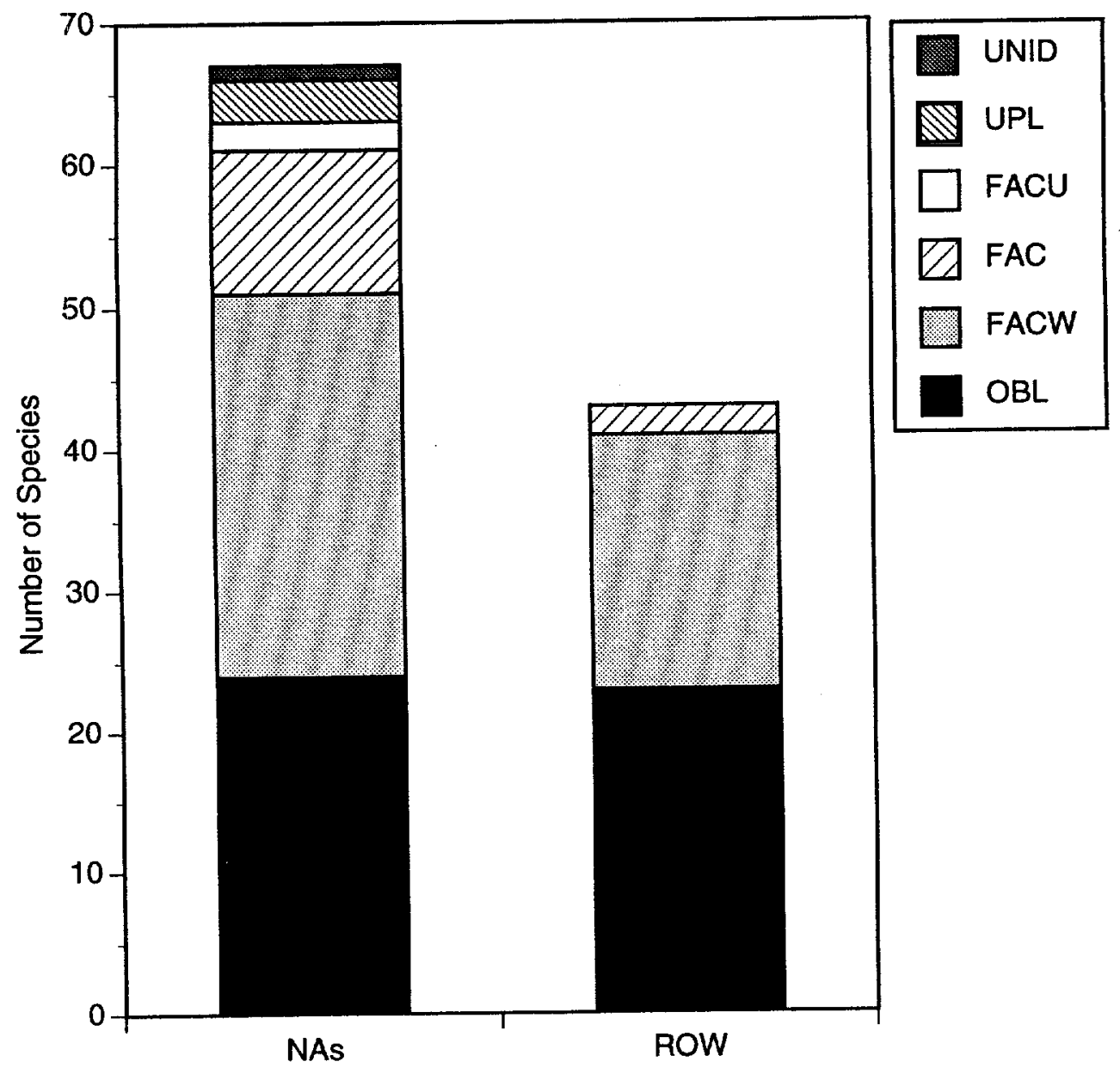

FIGURE 5 Number of Species in Each Wetland Indicator Category by Area

SNA, with 56 species, was more diverse than the NNA, which had 39 species. The NNA had a much denser shrub stratum than did the SNA; the sum of average coverages for individual shrubs was $114 \%$ for the NNA compared with $70.2 \%$ for the SNA. Approximately $75 \%$ of the species in each NA were OBL or FACW species. The distribution of OBL and FACW species across strata was also similar for both NAs.

Dominance. Dominant species, by stratum, and their relative percents cover (RPCs) are listed in Table 4. Average coverages, determined on the basis of five plots per area, are given in Table C. 3 for each species by stratum for each area. All dominant species in all areas are obligate wetland (OBL), facultative wetland (FACW), or facultative (FAC) species. The two ROWdominant species were OBL and FACW. The leading dominant species in the ROW was broadleaf cattail (Typha latifolia), and the second leading dominant species was purple loosestrife (Lythrum salicaria). These two species accounted for $65.6 \%$ of the total sum of RPCs for all species in the ROW. Both of these species were also common in the adjacent NAs, but they were less abundant. 


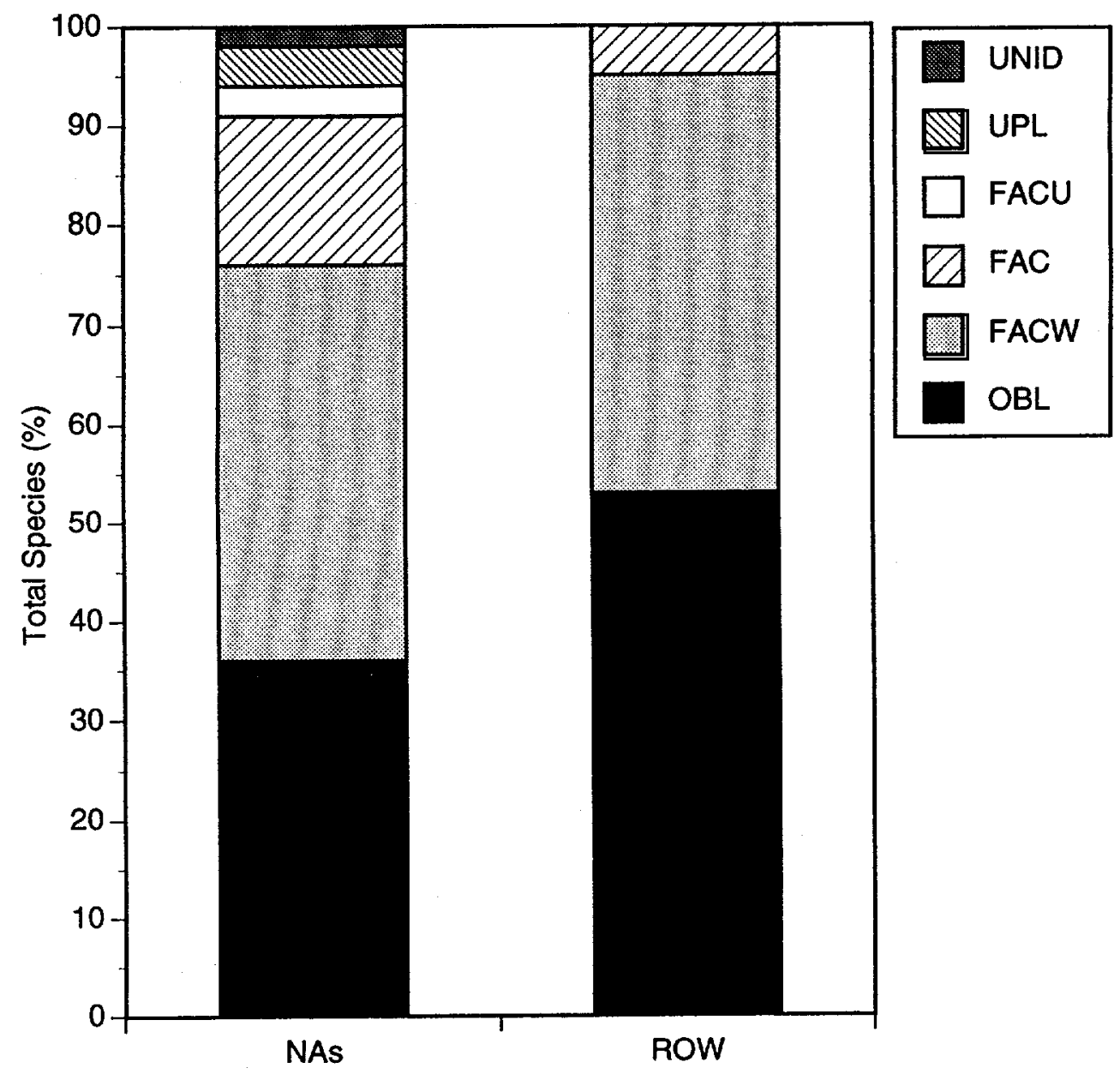

FIGURE 6 Percent of Species in Each Wetland Indicator Category by Area

The leading dominant species in the herb stratum of the NAs was common duckweed (Lemna minor), a small floating OBL plant that was much more abundant in the SNA than in the NNA. The second leading dominant, climbing nightshade (Solanum dulcamara), is an introduced species. The third dominant in the NAs was uptight sedge (Carex stricta), while the fourth was sensitive fern (Onoclea sensibilis). Thus, the herb stratum had four dominant species, each with a different life-form, and one was an introduced species.

Three species of shrubs were dominant in the NAs. All were native species, with one being OBL and two FACW. Seventeen other species were represented in the shrub stratum, providing a well-represented, diverse stratum - the sum of coverages for all species was $92.0 \%$.

Both the sapling and tree strata were poorly represented - only two species were present in the sapling stratum, and a single specimen was present in the tree stratum. Total areal cover for all saplings was $2.9 \%$, while total cover for all trees was $0.4 \%$. Both species of maples were wellrepresented in the shrub stratum, the average areal coverages of red maple and silver maple being 
TABLE 2 Number of Plant Species by Wetland Indicator Category Found in the Herb Stratum in the Study Plots in the North ROW and the South ROW

\begin{tabular}{lcccccc}
\hline & \multicolumn{5}{c}{ Number of Species } \\
\cline { 2 - 5 } $\begin{array}{l}\text { Wetland } \\
\text { Indicator } \\
\text { Category }\end{array}$ & $\begin{array}{c}\text { Occurring } \\
\text { in North } \\
\text { ROW }\end{array}$ & $\begin{array}{c}\text { Occurring } \\
\text { in South } \\
\text { ROW }\end{array}$ & $\begin{array}{c}\text { Common } \\
\text { to Both } \\
\text { ROWs }\end{array}$ & $\begin{array}{c}\text { Unique } \\
\text { to North } \\
\text { ROW }\end{array}$ & $\begin{array}{c}\text { Unique } \\
\text { to South } \\
\text { ROW }\end{array}$ & Total \\
\hline OBL & 22 & 14 & 13 & 9 & 1 & 23 \\
FACW & 15 & 15 & 12 & 3 & 3 & 18 \\
FAC & 2 & 0 & 0 & 2 & 0 & 2 \\
FACU & 0 & 0 & 0 & 0 & 0 & 0 \\
UPL & 0 & 0 & 0 & 0 & 0 & 0 \\
Unid & 0 & 0 & 0 & 0 & 0 & 0 \\
Total & 39 & 29 & 25 & 14 & 4 & 43 \\
\hline
\end{tabular}

a Unid $=$ plants not identified to species .

$5.6 \%$ and $7.5 \%$, respectively. Because saplings and trees were sparse and the number of species present in each stratum was low, both sapling species present and the single tree species ranked as dominants.

Coefficient of Community Similarity. Table 5 presents Sørensen's coefficient of community values $\left(\mathrm{CC}_{\mathrm{s}}\right.$; see Section 3.4 for an explanation), comparing species composition of areas by stratum. These values are based on the information in Tables 1-3. The comparison of the NAs with the ROW is limited to the herb stratum, the only stratum present in the ROW. A comparison of the two sides of the ROW yielded a similarity index of 0.73 , which indicates a relatively similar community of plant species. The similarity indices comparing the shrub and sapling strata in the two NAs also indicate similar communities ( 0.76 and 1.00 , respectively). The index comparing the herb stratum in the two NAs is only 0.57 , slightly less than the comparison between the herb stratum in the ROW and the NAs (an index of 0.58); thus, the herb community of the ROW appears to be as similar to that of the NAs as those of the NAs are to each other.

Prevalence Index Values and Average Wetland Values. Table 6 presents PIVs and AWVs for the combined ROW plots and the combined NA plots by stratum for all species and for dominant species only. All of the PIVs and AWVs for the herb stratum in the NAs and on the ROW were less than 2.00 , indicating the prevalence of wetland vegetation. Values for the ROW were lower than the comparable values for the NAs; therefore, more hydric vegetation was present in the herb stratum of the ROW than in the herb strata of the NAs. Values for dominant species only were similar to the values for all species. Values for the shrub, sapling, and tree strata were also under 3.00, indicating the presence of hydric vegetation in each of these strata. Values for the 
TABLE 3 Number of Plant Species by Wetland Indicator Category Found in the Study Plots in the NNA and SNA (by individual stratum and combined strata)

\begin{tabular}{|c|c|c|c|c|c|c|c|}
\hline \multirow[b]{2}{*}{ Stratum } & \multirow[b]{2}{*}{$\begin{array}{l}\text { Wetland } \\
\text { Indicator } \\
\text { Category }\end{array}$} & \multicolumn{6}{|c|}{ Number of Species } \\
\hline & & $\begin{array}{c}\text { Occurring } \\
\text { in } \\
\text { NNA }\end{array}$ & $\begin{array}{c}\text { Occurring } \\
\text { in } \\
\text { SNA }\end{array}$ & $\begin{array}{c}\text { Common } \\
\text { to Both } \\
\text { NAs }\end{array}$ & $\begin{array}{c}\text { Unique } \\
\text { to } \\
\text { NNA }\end{array}$ & $\begin{array}{c}\text { Unique } \\
\text { to } \\
\text { SNA }\end{array}$ & Total \\
\hline \multirow[t]{7}{*}{ Herb } & OBL & 12 & 16 & 6 & 6 & 10 & 22 \\
\hline & FACW & 15 & 22 & 13 & 2 & 9 & 24 \\
\hline & FAC & 4 & 7 & 3 & 1 & 4 & 8 \\
\hline & FACU & 1 & 2 & 1 & 0 & 1 & 2 \\
\hline & UPL & 1 & 2 & 1 & 0 & 1 & 2 \\
\hline & Unida & 0 & 1 & 0 & 0 & 1 & 1 \\
\hline & Total & 33 & 50 & 24 & 9 & 26 & 59 \\
\hline \multirow[t]{7}{*}{ Shrub } & $\mathrm{OBL}$ & 5 & 3 & 3 & 2 & 0 & 5 \\
\hline & FACW & 7 & 9 & 6 & 1 & 3 & 10 \\
\hline & FAC & 3 & 4 & 3 & 0 & 1 & 4 \\
\hline & FACU & 0 & 0 & 0 & 0 & 0 & 0 \\
\hline & UPL & 1 & 1 & 1 & 0 & 0 & 1 \\
\hline & Unid & 0 & 0 & 0 & 0 & 0 & 0 \\
\hline & Total & 16 & 17 & 13 & 3 & 4 & 20 \\
\hline \multirow[t]{7}{*}{ Sapling } & OBL & 0 & 0 & 0 & 0 & 0 & 0 \\
\hline & FACW & 1 & 1 & 1 & 0 & 0 & 1 \\
\hline & FAC & 1 & 1 & 1 & 0 & 0 & 1 \\
\hline & FACU & 0 & 0 & 0 & 0 & 0 & 0 \\
\hline & UPL & 0 & 0 & 0 & 0 & 0 & 0 \\
\hline & Unid & 0 & 0 & 0 & 0 & 0 & 0 \\
\hline & Total & 2 & 2 & 2 & 0 & 0 & 2 \\
\hline \multirow[t]{7}{*}{ Tree } & OBL & 0 & 0 & 0 & 0 & 0 & 0 \\
\hline & FACW & 0 & 1 & 0 & 0 & 1 & 1 \\
\hline & FAC & 0 & 0 & 0 & 0 & 0 & 0 \\
\hline & FACU & 0 & 0 & 0 & 0 & 0 & 0 \\
\hline & UPL & 0 & 0 & 0 & 0 & 0 & 0 \\
\hline & Unid & 0 & 0 & 0 & 0 & 0 & 0 \\
\hline & Total & 0 & 1 & 0 & 0 & 1 & 1 \\
\hline \multirow{7}{*}{$\begin{array}{l}\text { Combined } \\
\text { strata }\end{array}$} & OBL & 14 & 17 & 7 & 7 & 10 & 24 \\
\hline & FACW & 16 & 24 & 13 & 3 & 11 & 27 \\
\hline & FAC & 6 & 9 & 5 & 1 & 4 & 10 \\
\hline & FACU & 1 & 2 & 1 & 0 & 1 & 2 \\
\hline & UPL & 2 & 3 & 2 & 0 & 1 & 3 \\
\hline & Unid & 0 & 1 & 0 & 1 & 1 & 1 \\
\hline & Total & 39 & 56 & 28 & 12 & 28 & 67 \\
\hline
\end{tabular}

anid = plants not identified to species. 
TABLE 4 Dominant Species by Vegetative Stratum for Each Area

\begin{tabular}{|c|c|c|c|c|c|c|}
\hline Stratum & Area & Scientific Name & Common Name & $\begin{array}{l}\text { Wetland } \\
\text { Indicator } \\
\text { Category }\end{array}$ & $\begin{array}{c}\text { Relative } \\
\text { Percent } \\
\text { Cover }\end{array}$ & $\begin{array}{l}\text { Sum of } \\
\text { Relative } \\
\text { Percents } \\
\text { Cover }\end{array}$ \\
\hline Herb & NAs & $\begin{array}{l}\text { Lemna minor } \\
\text { Solanum dulcamara } \\
\text { Carex stricta } \\
\text { Onoclea sensibilis }\end{array}$ & $\begin{array}{l}\text { Common duckweed } \\
\text { Climbing nightshade } \\
\text { Uptight sedge } \\
\text { Sensitive fern }\end{array}$ & $\begin{array}{l}\text { OBL } \\
\text { FAC } \\
\text { OBL } \\
\text { FACW }\end{array}$ & $\begin{array}{r}22.9 \\
13.2 \\
12.4 \\
6.4\end{array}$ & 54.9 \\
\hline & ROW & $\begin{array}{l}\text { Typha latifola } \\
\text { Lythrum salicaria }\end{array}$ & $\begin{array}{l}\text { Broad-leaf cattail } \\
\text { Purple loosestrife }\end{array}$ & $\begin{array}{l}\text { OBL } \\
\text { FACW }\end{array}$ & $\begin{array}{l}47.0 \\
18.6\end{array}$ & 65.6 \\
\hline Shrub & NAs & $\begin{array}{l}\text { Cornus amomum } \\
\text { Cornus stolonifera } \\
\text { Rosa palustris }\end{array}$ & $\begin{array}{l}\text { Silky dogwood } \\
\text { Red-osier dogwood } \\
\text { Swamp rose }\end{array}$ & $\begin{array}{l}\text { FACW } \\
\text { FACW } \\
\text { OBL }\end{array}$ & $\begin{array}{l}31.8 \\
15.5 \\
15.2\end{array}$ & 62.5 \\
\hline Sapling & NAs & $\begin{array}{l}\text { Acer rubrum } \\
\text { Acer saccharinum }\end{array}$ & $\begin{array}{l}\text { Red maple } \\
\text { Silver maple }\end{array}$ & $\begin{array}{l}\text { FAC } \\
\text { FACW }\end{array}$ & $\begin{array}{l}55.2 \\
44.8\end{array}$ & 100 \\
\hline Tree ${ }^{a}$ & NAs & Acer saccharinum & Silver maple & FACW & 100 & 100 \\
\hline
\end{tabular}

a Only one tree was found in the tree stratum of the wetland area.

TABLE 5 Coefficient of Community Values Comparing Similarity of Species Occurring in Study Plots

\begin{tabular}{lccc} 
& \multicolumn{3}{c}{$\mathrm{CC}_{\mathrm{s}}$ for Given Comparison } \\
\cline { 2 - 4 } Stratum & $\begin{array}{c}\text { NAs to } \\
\text { ROW }\end{array}$ & $\begin{array}{c}\text { North ROW to } \\
\text { South ROW }\end{array}$ & NNA to SNA \\
\hline Herb & 0.58 & 0.73 & 0.57 \\
Shrub & 0.00 & 0.00 & 0.76 \\
Sapling & 0.00 & 0.00 & 1.00 \\
Tree & 0.00 & 0.00 & 0.00 \\
$\begin{array}{l}\text { Combined } \\
\text { strata }\end{array}$ & 0.53 & 0.73 & 0.66 \\
\hline
\end{tabular}


TABLE 6 Prevalence Index and Average Wetland Values for All Species and Dominant Species Found in the NAs and the ROW (by individual stratum and combined strata)

\begin{tabular}{|c|c|c|c|c|}
\hline Stratum & Area & Species & $\begin{array}{c}\text { Prevalence Index } \\
\text { Value }\end{array}$ & $\begin{array}{c}\text { Average Wetland } \\
\text { Value }\end{array}$ \\
\hline \multirow[t]{2}{*}{ Herb } & NAs & $\begin{array}{l}\text { All } \\
\text { Dominants only }\end{array}$ & $\begin{array}{l}1.75 \\
1.60\end{array}$ & $\begin{array}{l}1.93 \\
1.75\end{array}$ \\
\hline & ROW & $\begin{array}{l}\text { All } \\
\text { Dominants only }\end{array}$ & $\begin{array}{l}1.29 \\
1.28\end{array}$ & $\begin{array}{l}1.51 \\
1.50\end{array}$ \\
\hline \multirow[t]{2}{*}{ Shrub } & NAs & $\begin{array}{l}\text { All } \\
\text { Dominants only }\end{array}$ & $\begin{array}{l}2.05 \\
1.76\end{array}$ & $\begin{array}{l}2.14 \\
1.25\end{array}$ \\
\hline & ROWa & & none & none \\
\hline \multirow[t]{2}{*}{ Sapling } & NAs & $\begin{array}{l}\text { All } \\
\text { Dominants only }\end{array}$ & $\begin{array}{l}2.55 \\
2.55\end{array}$ & $\begin{array}{l}2.50 \\
2.50\end{array}$ \\
\hline & ROWa & & none & none \\
\hline \multirow[t]{2}{*}{ Tree } & NAs & $\begin{array}{l}\text { All } \\
\text { Dominants only }\end{array}$ & $\begin{array}{l}2.00 \\
2.00\end{array}$ & $\begin{array}{l}2.00 \\
2.00\end{array}$ \\
\hline & ROWa & & none & none \\
\hline \multirow{2}{*}{$\begin{array}{l}\text { Combined } \\
\text { strata }\end{array}$} & NAs & All & $N C^{b}$ & 1.98 \\
\hline & ROW & All & NC & 1.51 \\
\hline
\end{tabular}

a No shrubs, saplings, or trees were present on the ROW.

b $\mathrm{NC}=$ not calculated. Values could not be calculated for combined strata because areal cover (which is not additive) is used in its calculation.

dominant species in the tree and sapling strata were identical to those for all species because these strata had only one and two species, respectively. All species present in the sapling and tree strata were dominant. The lower value for dominant species in the shrub stratum indicates the presence of dominant species that are more hydric than the average for that stratum. The PIVs and AWVs for the ROW were lower than for any stratum in the NAs. 


\section{Discussion}

Before construction, the site was delineated as a wetland. Soil, hydrology, and vegetative data indicate that both the NAs and the ROW remain wetlands after construction. Although no evidence exists that the presence of the ROW had altered adjacent NAs, the ROW itself had been altered from preconstruction conditions as a result of clear-cutting and the use of open-trench technologies to install the pipeline. As a result of pipeline installation, the microtopography of the ROW had changed - the center was slightly higher and a number of small depressions were created near the north edge. The ROW also lacked woody vegetation.

Within two years of pipeline installation, the ROW had developed a dense herbaceous vegetative community that was dominated by cattail and purple loosestrife, neither of which was dominant in the adjacent NAs, although both occurred there. Three factors may have contributed to the greater abundance of these species in the ROW than in the NAs. First, the lack of competition with shrubs, saplings, and trees may have allowed these aggressive, sun-adapted herbs to become more abundant. Second, the changes in the microtopography of the ROW may have enhanced the growth of purple loosestrife, which appeared to favor higher elevations. Third, the disturbance of ROW soils during construction activities would have favored plants with high seed production, rapid germination, and vigorous, sun-adapted seedlings.

The reestablishment of 30 of the 67 species found in adjacent NAs within two years demonstrated the inherent ability of this wetland to revegetate the ROW. Although construction plans called for seeding of the ROW with an annual grass, there was no evidence of seeding, and it cannot be confirmed that actual seeding occurred. The dense vegetative cover (an approximate $200 \%$ sum of coverages for all species) in the ROW further demonstrates the natural ability of the ROW for revegetating itself.

Of the 37 species found in the NAs but not in the ROW, 10 were woody shrub and tree species, which are generally considered undesirable in the ROW. At least some of the remaining 27 species are shade-adapted and may not reinvade the ROW. However, even without these species, the ROW already has considerable diversity, with 47 species present.

The low PIVs and AWVs for ROW dominants and all ROW species confirm that the ROW flora have a greater fidelity to wetlands than do the flora in the adjacent NAs. This phenomenon can be attributed, in part, to the lack of larger woody specimens, which may have wider ecological tolerances, and the lack of more mesic-specific habitats (such as the small hummocks associated with larger shrubs and tussock-forming sedges).

The construction of a pipeline ROW through the scrub-shrub community at this site has led to a ROW vegetative community that was still less diverse in terms of numbers of species present and plant life-forms represented but more hydric than that occurring in the adjacent NAs. Pipeline construction contributed to overall species and habitat diversity in the wetland. Although pipeline construction fragments the scrub-shrub habitat, it provides habitat diversity and additional edge habitat. Revegetation of the ROW was rapid but involved two aggressive species, broad-leaf 
cattail and purple loosestrife. Although rapid revegetation is desirable, these two species are often considered undesirable. 


\section{Summary and Conclusions}

\subsection{Summary}

The primary goal of the GRI Wetland Corridors Program is to identify and evaluate the impacts of pipeline construction and ROW maintenance on the wetlands they traverse. To accomplish this goal, pipelines crossing various wetlands throughout the eastern United States were surveyed. The objectives for each study site were to document the vegetative communities on the ROW and in adjacent NAs that had not been disturbed by pipeline construction; to evaluate the similarities and differences between the plant communities on the ROW and those in the adjacent NAs; to document qualitative changes to the topography, soils, and hydrology attributable to ROW construction; and to identify the impacts caused by ROW construction on rare, threatened, endangered, or sensitive species.

This study involved the collection and analysis of data at a site within the Norris Brook crossing of a pipeline in Peabody, Essex County, Massachusetts. The pipeline had been installed approximately 22 months prior to the collection of field data. The site was located within a scrubshrub wetland that constituted the western one-third of the Norris Brook floodplain along the pipeline route. This site was of particular interest because it is a scrub-shrub wetland and because of the short time that had passed since pipeline construction. The data collected in this study can also serve as baseline data for future studies at this site to determine long-term impacts of pipeline construction on this wetland.

The results of the vegetational survey indicate that within two years, a dense vegetative community, consisting predominantly of native species ( $70 \%$ of which were also present in the adjacent NAs), has become established on the ROW. This community consists of an herb stratum that is denser than that in the adjacent NAs. The new vegetative community is also more hydric, as indicated by lower PIVs and AWVs. This community is possible because of favorable hydrological conditions and the lack of competition with trees and shrubs within the newly created ROW.

Minor changes in site topography may have influenced the types of dominant species that occur in this new community and retarded development of vegetation in depressions in the ROW. Follow-up studies would be valuable to determine whether succession will lead to a decrease in dominance by cattails and purple loosestrife.

\subsection{Conclusions}

The most obvious impact of the construction of the pipeline through this wetland is the absence of shrubs, saplings, and trees from the ROW. Reestablishment of native and naturally invading introduced species has led to rapid revegetation of the ROW. Most of the species in the 
ROW are native perennials, $70 \%$ of which occur in the adjacent NAs. Artificial seeding was not necessary.

Two years after pipeline installation, the ROW had wetland vegetation, wetland hydrology, and wetland soils. It continued to function as a wetland. The ROW contributes to habitat diversity and species diversity for this wetland. The extent to which the ROW has developed a desirable vegetative community within two years is documented by this study. Additional surveys of the site are recommended to determine the extent to which purple loosestrife may become a problem and to document other successional trends on the ROW as normal maintenance is carried out. 


\section{References}

Bonham, C.P., 1989, Measurements for Terrestrial Vegetation, John Wiley and Sons, New York, N.Y.

Brower, J., J. Zar, and C. von Ende, 1990, Field and Laboratory Methods for General Ecology, Third Edition, Wm. C. Brown Publishers, Dubuque, Iowa.

Cowardin, L.M., et al., 1979, Classification of Wetlands and Deep Water Habitats of the United States, U.S. Fish and Wildlife Service, U.S. Geological Survey, and U.S. National Oceanic and Atmospheric Administration, Washington, D.C.

Federal Interagency Committee for Wetland Delineation, 1989, Federal Manual for Identifying and Delineating Jurisdictional Wetlands, U.S. Army Corps of Engineers, U.S. Environmental Protection Agency, U.S. Fish and Wildlife Service, and U.S. Department of Agriculture, Washington, D.C., Cooperative Technical Publication.

FICWD: See Federal Interagency Committee for Wetland Delineation.

Reed, P.B., Jr., 1988, National List of Plant Species That Occur in Wetlands: Southeast (Region 2), Biology Report 88 (26.2), U.S. Department of Interior, Fish and Wildlife Service.

SCS: See Soil Conservation Service.

Soil Conservation Service, 1991, Hydric Soils of the United States, U.S. Department of Agriculture, in cooperation with the National Technical Committee for Hydric Soils.

Soil Conservation Service, 1984, Soil Survey of Essex County, Massachusetts, Southern Part, United States Department of Agriculture, in cooperation with the Massachusetts Agricultural Experiment Station.

State of Massachusetts, 1991, Massachusetts List of Endangered, Threatened, and Special Concern Species Occurring at Section 10-60 of Chapter 321 of the Code of Massachusetts Regulations Pertaining to the Massachusetts Endangered Species Act (M.G.L.c13Ia), State of Massachusetts Executive Office of Environmental Affairs.

Zimmerman, R.E., et al., 1991, Pipeline Corridors through Wetlands - Impacts on Plant and Avian Diversity: Boreal Wetlands, Oconto County, Wisconsin, Topical Report GRI-91/0046, prepared by Argonne National Laboratory, Argonne, Ill., for the Gas Research Institute, Chicago, Ill. 


\section{Appendix A:}

Definition of Jurisdictional Wetlands 


\section{Appendix A: Definition of Jurisdictional Wetlands}

Wetland identification and delineation necessary to implement Section 404 of the Clean Water Act and the "Swampbuster" (Subtitle B) provision of the Food Security Act of 1985 involves four agencies: the U.S. Army Corps of Engineers (COE), the U.S. Environmental Protection Agency (EPA), the U.S. Fish and Wildlife Service (FWS), and the Soil Conservation Service (SCS). On January 10, 1989, these agencies, which had operated with slightly different definitions of wetland, adopted a uniform definition based on hydrology, vegetation, and soils.

The joint agreement stipulates that to be classified as a Jurisdictional Wetland, an area must have hydrotrophytic vegetation, hydric soils, and a wetland hydrology. All three criteria are mandatory; without any one criterion, the area is not a Jurisdictional Wetland. A schematic diagram of this delineation process is shown in Figure A.1. See the Federal Manual for Identifying and Delineating Jurisdictional Wetlands for a more detailed discussion of the various terms and criteria (FICWD 1989).

Problems uncovered during field trials of the 1989 Federal Manual and disagreement among the four agencies on revisions in 1991 resulted in the EPA and the COE reverting to use of the 1987 COE Wetlands Delineation Manual, which also defines wetlands on the basis of vegetation, hydric soils, and hydrology, but with slightly different definitions of these parameters. In January 1994, the four agencies entered into a joint Memorandum of Agreement, "Concerning the Delineation of Wetlands for Purposes of Section 404 of the Clean Water Act and Subtitle B of the Food Security Act," which, in broad terms, stipulates that the EPA and the COE will accept SCS procedures for delineating wetlands (SCS 1988) on agricultural lands and that SCS will use the 1987 COE Wetlands Delineation Manual (COE 1987) for areas that are not agricultural lands.

The individual reports on the pipeline crossings through wetlands that are part of the GRI Wetland Corridors Program use the definition and criteria of the 1989 Federal Manual that were in effect during 1990 and 1991, the first two years of these studies. The use of the rigorous criteria of the 1989 manual should provide sufficient information for application to other procedures in the evolving field regulatory procedures for delineation and preservation of jurisdictional wetlands.

\section{References}

COE: see U.S. Army Corps of Engineers.

Federal Interagency Committee for Wetland Delineation, 1989, Federal Manual for Identifying and Delineating Jurisdictional Wetlands, U.S. Army Corps of Engineers, U.S. Environmental Protection Agency, U.S. Fish and Wildlife Service, and U.S. Department of Agriculture, Cooperative Technical Publication, Washington, D.C.

FICWD: see Federal Interagency Committee for Wetland Delineation. 
SCS: see Soil Conservation Service.

Soil Conservation Service, 1988, National Food Security Act Manual, U.S. Department of Agriculture, Washington, D.C.

U.S. Army Corps of Engineers, 1987, Corps of Engineers Wetlands Delineation Manual, Technical Report Y-87-1, Waterways Experiment Station, Vicksburg, Miss.

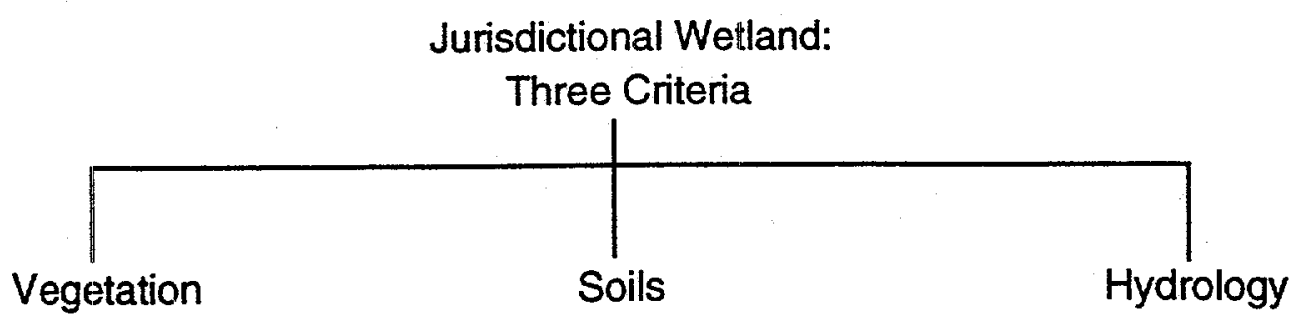

$1.50 \%$ dominant species $\mathrm{OBL}, \mathrm{FACW}$, and/or FAC or

2. Prevalence Index $<3.0$

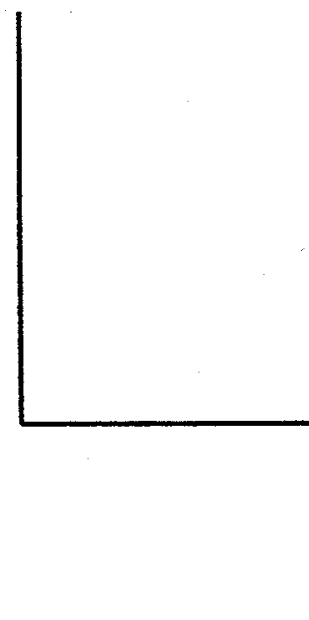

NTCHS Criteria

1. Histosols

or

2. Specific suborders that are poorly drained or

3. Soils ponded for 7 days or more during growing season or

4. Soils frequently flooded for long duration during growing season
1. Saturated for 7 days or more during growing season

or

2. Flooded or ponded for 7 days or more during growing season

If all three criteria are met,

area is a

regulated wetland

FIGURE A.1 Schematic Diagram of the Wetland Delineation Process (Source: FICWD 1989) 


\section{Appendix B:}

Data Analysis - Definitions and Equations 


\section{Appendix B: Data Analysis - Definitions and Equations}

\section{B.1 Wetland Indicator Categories}

Wetland indicator categories used in this report to classify the types of plant species were taken from Reed (1988). The five basic categories, commonly called the "wetland indicator status," are based on frequency of occurrence in wetlands. They are defined as follows:

\begin{tabular}{lcl}
\hline \multicolumn{1}{c}{ Category } & Value & \multicolumn{1}{c}{ Definition } \\
\hline Obligate wetland (OBL) & 1.0 & $\begin{array}{l}\text { Plants that almost always occur in wetlands under } \\
\text { natural conditions (estimated probability }>99 \%)\end{array}$ \\
$\begin{array}{l}\text { Facultative wetland } \\
\text { (FACW) }\end{array}$ & 2.0 & $\begin{array}{l}\text { Plants that usually occur in wetlands (estimated } \\
\text { probability } 67-99 \%) \text { but occasionally are found in } \\
\text { nonwetlands }\end{array}$ \\
$\begin{array}{l}\text { Facultative (FAC) } \\
\text { Facultative upland } \\
\text { (FACU) }\end{array}$ & 3.0 & $\begin{array}{l}\text { Plants that are equally likely to occur in wetlands or } \\
\text { nonwetlands (estimated probability } 34-66 \%)\end{array}$ \\
Obligate upland (UPL) & 4.0 & $\begin{array}{l}\text { Plants that usually occur in nonwetlands (estimated } \\
\text { probability 67-99\%) but occasionally are found in } \\
\text { wetlands (estimated probability 1-33\%) }\end{array}$ \\
\hline
\end{tabular}




\section{B.2 Life-Form and Origin}

The life-form and origin symbols are used for describing plant characteristics. The following symbols are used:

\begin{tabular}{cl}
\hline & \\
Symbol & Life-Form or Origin \\
\hline A & Annual \\
B & Biennial \\
E & Emergent \\
F & Forb \\
F3 & Fern \\
G & Grass \\
GL & Grasslike \\
H2 & Horsetail \\
I & Introduced \\
N & Native \\
P & Perennial \\
S & Shrub \\
$T$ & Tree \\
V & Herbaceous vine \\
WV & Woody vine \\
\hline
\end{tabular}

Symbols are combined to describe the life-form and origin; for example, ANG means annual native grass and PIEF means perennial introduced emergent forb. For further description refer to the report by Reed (1988).

\section{B.3 Prevalence Index Value}

The prevalence index value (PIV) was determined by using the method outlined in the 1989 Federal Manual (FICWD 1989). The PIV, modified for this report to use relative percent areal coverage instead of relative frequencies as described in the 1989 Federal Manual, is defined as

$$
\mathrm{PIV}=\frac{\mathrm{RPC}_{0}+2 \mathrm{RPC}_{\mathrm{fw}}+3 \mathrm{RPC}_{\mathrm{f}}+4 \mathrm{RPC}_{\mathrm{fu}}+5 \mathrm{RPC}_{\mathrm{u}}}{100}
$$

where

$$
\begin{aligned}
\mathrm{RPC}_{\mathrm{o}} & =\text { Relative percent coverage (RPC) of obligate wetland species, } \\
\mathrm{RPC}_{\mathrm{fw}} & =\mathrm{RPC} \text { of facultative wetland species, }
\end{aligned}
$$


$\mathrm{RPC}_{\mathrm{f}}=\mathrm{RPC}$ of facultative species,

$\mathrm{RPC}_{\mathrm{fu}}=\mathrm{RPC}$ of facultative upland species, and

$\mathrm{RPC}_{\mathrm{u}}=\mathrm{RPC}$ of upland species.

\section{B.4 Average Wetland Value}

The average wetland value (AWV), defined in Zimmerman et al. (1991), differs from the PIV in that it is not coverage data or frequency of occurrence that is used in determining the AWV, but rather the total number of species present. Thus, all species present are represented equally in the AWV. The AWV is defined as

$$
A W V=\frac{N_{o}+2 N_{f w}+3 N_{f}+4 N_{f u}+5 N_{u}}{N_{o}+N_{f w}+N_{f}+N_{f u}+N_{u}}
$$

where

$$
\begin{aligned}
N_{0} & =\text { number of obligate wetland species, } \\
N_{f w} & =\text { number of facultative wetland species, } \\
N_{f} & =\text { number of facultative species, } \\
N_{f u} & =\text { number of facultative upland species, and } \\
N_{u} & =\text { number of upland species. }
\end{aligned}
$$

\section{B.5 References}

Federal Interagency Committee for Wetland Delineation, 1989, Federal Manual for Identifying and Delineating Jurisdictional Wetlands, U.S. Army Corps of Engineers, U.S. Environmental Protection Agency, U.S. Fish and Wildlife Service, and U.S. Department of Agriculture, Cooperative Technical Publication, Washington, D.C.

FICWD: see Federal Interagency Committee for Wetland Delineation. 
Reed, P.B., Jr., 1988, National List of Plant Species that Occur in Wetlands, Region 1, Biology Report 88 (26.1), U.S. Department of the Interior.

Zimmerman, R.E., et al., 1991, Pipeline Corridors through Wetlands - Impacts on Plant and Avian Diversity: Boreal Wetlands, Oconto County, Wisconsin, Topical Report GRI-91/0046, prepared by Argonne National Laboratory, Argonne; III., for the Gas Research Institute, Chicago, III. 
Appendix C:

Plant Species List, Areal Coverage Data, and Species Distributions 


\section{Appendix C:}

\section{Plant Species List, Areal Coverage Data, and Species Distributions}

TABLE C.1 Plant Species List for Norris Brook Crossing

\begin{tabular}{|c|c|c|c|c|}
\hline $\begin{array}{l}\text { Field } \\
\text { Number }\end{array}$ & Scientific Name and Authority & Common Name & $\begin{array}{l}\text { Region } 1 \\
\text { Wetland } \\
\text { Indicator } \\
\text { Categorya }\end{array}$ & $\begin{array}{l}\text { Life- } \\
\text { Form/ } \\
\text { Origin }^{b}\end{array}$ \\
\hline 77 & Acer rubrum $\mathrm{L}$. & Red maple & FAC & NT \\
\hline 19 & Acer saccharinum ${ }^{C} \mathrm{~L}$. & Silver maple & FACW & NT \\
\hline 44 & Agrostis stolonifera L. & Spreading bentgrass & FACW & PNG \\
\hline 39 & Alisma subcordatum Raf. & Subcordate water-plantain & OBL & PNEF \\
\hline 36 & Alnus rugosa (Du Roi) Spreng. & Speckled alder & FACW+ & NT \\
\hline 65 & Apios Americana Medic. & American potato-bean & FACW & PNF \\
\hline 63 & Aronia arbutifolia (L.) Elliott & Red chokeberry & FACW & NS \\
\hline 85 & Asclepias incarnata $\mathrm{L}$. & Swamp milkweed & OBL & PNF \\
\hline 64 & Aster prenanthoides ${ }^{d}$ Muhl. & Crooked-stem aster & FAC & PNF \\
\hline 22 & Aster simplex Willd. & Panicled aster & FACW & PNF \\
\hline 10 & Bidens connata Muhl. ex Willd. & Purple-stem beggar-ticks & $\mathrm{FACW}_{+}$ & ANF \\
\hline 8 & Bidens frondosa $\mathrm{L}$. & Devil's beggar-ticks & FACW & ANF \\
\hline 2 & Boehmeria cylindrica (L.) Swartz & Small-spike false-nettle & FACW+ & PNF \\
\hline 15 & $\begin{array}{l}\text { Calamagrostis canadensis (Michx.) } \\
\text { Beauv }\end{array}$ & Blue-joint reedgrass & FACW+ & PNG \\
\hline 67 & Campanula aparanoides Pursh & Marsh bellflower & OBL & PNF \\
\hline 45 & Carex comosa Boott & Bearded sedge & OBL & PNEGL \\
\hline 71 & Carex projecta Machenz. & Necklace sedge & FACW & PNGL \\
\hline 91 & Carex scoparia Schkuhr ex Willd. & Pointed broom sedge & FACW & PNGL \\
\hline 13 & Carex stricta Lam. & Uptight sedge & OBL & PNEGL \\
\hline 92 & Carex vulpinoidea Michx. & Fox sedge & OBL & PNEGL \\
\hline 82 & Carex $\times$ stipata Muhl. ex Willd. & Stalk-grain sedge & OBL & PNGL \\
\hline 31 & Cephalanthus occidentalis $\mathrm{L}$. & Common buttonbush & OBL & NT \\
\hline 5 & Cicuta bulbifera $\mathrm{L}$. & $\begin{array}{l}\text { Bulblet-bearing water- } \\
\text { hemlock }\end{array}$ & $\underset{*}{\mathrm{OBL}}$ & PNF \\
\hline 28 & Cinna arundinaceae $\mathrm{L}$. & Stout wood-reedgrass & FACW+ & PNG \\
\hline 20 & Clethra alnifolia L. & Coast pepper-bush & FAC+ & NS \\
\hline 52 & Cornus amomum Mill. & Silky dogwood & FACW & NS \\
\hline 33 & Cornus stolonifera Michx. & Red-osier dogwood & FACW+ & NS \\
\hline 51 & Cuscuta gronovii Willd. ex Schultz & Gronova's dodder & UPL & ANV+ \\
\hline 93 & Cyperus strigosus $\mathrm{L}$. & Straw-color flatsedge & FACW & PNEGL \\
\hline 86 & $\begin{array}{l}\text { Dryopteris spinulosa (O.F. Muell.) } \\
\text { Watt }\end{array}$ & Spinulose woodfern & $\mathrm{FAC}+$ & F3 \\
\hline 73 & $\begin{array}{l}\text { Eleocharis obtusa (Willd.) } \\
\text { J.A. Schultes }\end{array}$ & Blunt spikerush & OBL & APNEGL \\
\hline 94 & Elodea canadensis Michx. & Broad water-weed & OBL & PNZF \\
\hline 50 & Epilobium coloratum Biehler & Purple-leaf willow-herb & OBL & PNF \\
\hline
\end{tabular}


TABLE C.1 (Cont.)

\begin{tabular}{|c|c|c|c|c|}
\hline $\begin{array}{l}\text { Field } \\
\text { Number }\end{array}$ & Scientific Name and Authority & Common Name & $\begin{array}{l}\text { Region } 1 \\
\text { Wetland } \\
\text { Indicator } \\
\text { Category }\end{array}$ & $\begin{array}{l}\text { Life- } \\
\text { Form/ } \\
\text { Origin }\end{array}$ \\
\hline 38 & $\begin{array}{l}\text { Eupatoriadelphus maculatus (L.) } \\
\text { R.M. King and H. Rob. }\end{array}$ & Spotted Joe-pye-weed & FACW & PNF \\
\hline 78 & Euthamia graminifolia (L.) Nutt. & $\begin{array}{l}\text { Flat-top tragrant-golden- } \\
\text { rod }\end{array}$ & FAC & PNF \\
\hline 26 & Galium obtusum Bigel. & Blunt-leaf bedstraw & FACW+ & PNF \\
\hline 12 & Galium trifidum L. & Small bedstraw & FACW+ & PNF \\
\hline 62 & Ilex verticillata (L.) Gray & Common winterberry & $\mathrm{FACW}_{+}$ & NTS \\
\hline 7 & Impatiens capensis Meerb. & Spotted touch-me-not & FACW & ANF \\
\hline 29 & Iris versicolor $\mathrm{L}$. & Virginia blueflag & OBL & PNF \\
\hline 41 & Juncus canadensis J. Gay & Canada rush & OBL & PNGL \\
\hline 42 & Juncus effusus $L$. & Soft rush & $\mathrm{FACW}_{+}$ & PNEGL \\
\hline 14 & Leersia oryzoides (L.) Swartz & Rice cutgrass & OBL & PNG \\
\hline 0 & Lemna minor L. & Common duckweed & OBL & $\mathrm{PN} / \mathrm{F}$ \\
\hline 74 & Ludwegia palustris (L.) Elliott & Marsh seedbox & $\mathrm{OBL}$ & PNEF \\
\hline 6 & Lycopus uniflorus Michx. & Northern bubleweed & OBL & PNF \\
\hline 25 & Lythrum salicaria $L$. & Purple loosestrife & $\mathrm{FACW}_{+}$ & PIF \\
\hline 27 & Maianthemum canadense Desf. & Wild lily-of-the-valley & FAC- & PNF \\
\hline 24 & Mentha arvensis L. & Field mint & $\mathrm{OBL}$ & PNF \\
\hline 90 & Moss & Moss & & \\
\hline 58 & Myrica gale L. & Sweetgale & OBL & NS \\
\hline 0 & Onoclea sensibilis L. & Sensitive fern & FACW & PNEF3 \\
\hline 81 & Osmunda cinnamomea $\mathrm{L}$. & Cinnamon fern & FACW & PNEF3 \\
\hline 32 & Osmunda regalis $\mathrm{L}$. & Royal fern & OBL & PNEF3 \\
\hline 75 & Poa trivales $\mathrm{L}$. & Rough bluegrass & FACW & $P I G$ \\
\hline 4 & Polygonum arifolium L. & Halberd-leaf tearthumb & OBL & ANEF \\
\hline 95 & Polygonum hydropiperoides Michx. & Swamp smartweed & OBL & PNEF \\
\hline 96 & Polygonum lapathifolium L. & Willow-weed & FACW+ & ANF \\
\hline 43 & Polygonum punctatum Elliott & Dotted smartweed & $\mathrm{OBL}$ & PNEF \\
\hline 66 & Quercus sp. (seedling) & & & PNF \\
\hline 37 & Rhamnus cathartica $L$. & Common buckthom & UPL & IT \\
\hline 17 & Rhamnus frangula $\mathrm{L}$. & Glossy buckthorn & FAC & is \\
\hline 57 & Rhododendron viscosumum (L.) Torr. & Swamp azalea & OBL & NS \\
\hline 97 & Rorippa palustris (L.) Besser & Bog yellow-cress & $\mathrm{OBL}$ & ANEF \\
\hline 70 & Rosa palustris Marshall & Swamp rose & $\mathrm{OBL}$ & NS \\
\hline 23 & Rubus allegheniensis T. Porter & Allegheny blackberry & FACU- & NS \\
\hline 83 & Rumex orbiculatus Gray & Great water dock & OBL & PNEF \\
\hline 40 & Sagitaria latifolia Willd. & Broad-leaf arrow-head & $\mathrm{OBL}$ & PNEF \\
\hline 98 & Salix bebbiana Sarg. & Bebb willow & FACW & NS \\
\hline 46 & Salix discolor Muhl. & Pussy willow & FACW & NS \\
\hline 60 & Salix petiolaris J.E. Smith & Meadow willow & $\mathrm{OBL}$ & NS \\
\hline 99 & Scirpus atrovirens Willd. & Green bulrush & $\mathrm{OBL}$ & PNEGL \\
\hline 55 & Scirpus cyperinus (L.) Kunth & Wool-grass & FACW+ & PNEGL \\
\hline 48 & Scirpus validus Vahl & Soft-stem bulrush & OBL & PNEGL \\
\hline 9 & Scutellaria galericulata L. & Hooded skullcap & OBL & PNF \\
\hline 49 & Sium suave Walter & Hemlock water-parsnip & OBL & PNEF \\
\hline
\end{tabular}




\begin{tabular}{|c|c|c|c|c|}
\hline $\begin{array}{l}\text { Field } \\
\text { Number }\end{array}$ & Scientific Name and Authority & Common Name & $\begin{array}{l}\text { Region } 1 \\
\text { Wetland } \\
\text { Indicator } \\
\text { Category }\end{array}$ & $\begin{array}{l}\text { Life- } \\
\text { Form/ } \\
\text { Origin }\end{array}$ \\
\hline 3 & Solanum dulcamara $L$. & Climbing nightshade & FAC- & PIF \\
\hline 80 & Solidago gigantea Ait. & Giant golden-rod & FACW & PNF \\
\hline 11 & Solidago nemoralis Ait. & Gray golden-rod & UPL & PNF \\
\hline 68 & Solidago uliginosa Nutt. & Bog golden-rod & $\mathrm{OBL}$ & PNF \\
\hline 56 & $\begin{array}{l}\text { Sparganium eurycarpum Engelm. } \\
\text { ex Gray }\end{array}$ & Giant burreed & OBL & PNEF \\
\hline 34 & Spirea latifolia (Ait.) Borkh. & Broad-leaf meadow-sweet & $\mathrm{FAC}+$ & NS \\
\hline 16 & Spirea tomentosa $\mathrm{L}$. & Steeple-bush & FACW & NS \\
\hline 76 & Symplocarpus foetidus (L.) Salisb. & Skunk-caggage & OBL & PNF \\
\hline 1 & $\begin{array}{l}\text { Thelypteris thelypteroides (Michx.) } \\
\text { J. Holub. }\end{array}$ & Marsh fern & FACW+ & F3 \\
\hline 0 & Toxicodendron radicans (L.) Kuntze & Poison ivy & FACU & NWVS \\
\hline 0 & Typha latifolia $\mathrm{L}$. & Broad-leaf cattail & OBL & PNEF \\
\hline 79 & Ulmus americanus $\mathrm{L}$. & American elm & FACW- & NT \\
\hline 21 & Vaccinium corymbosum L. & Highbush blueberry & FACW-NS & PNF \\
\hline 18 & Viburnum recognitum Fernald & Northern arrow-wood & FAC- & NS \\
\hline 84 & Vitis labrusca L.H. Bailey & Fox grape & FACU & IWV \\
\hline
\end{tabular}

a Wetland indicator categories are assigned to plants in the United States on a regional basis. Massachusetts is in Region 1. A " + " following an indicator category indicates a frequency toward the high end of the category (more frequently found in wetlands), while a "-" indicates a frequency toward the low end of the category (less frequently found in wetlands).

b Plant characteristics and life-forms assigned to each species are indicated in this column. See Section B.2 in Appendix B for definitions of life-forms and origins.

c Most specimens were crosses of $A$. saccharina with $A$. rubrum, which have recently been called A. fremonii Murr.

d Note that Aster prenanthoides is on the plants of special concern list for Massachusetts.

e Includes members of T. $\times$ glauca, which could not be distinguished in the vegetative state. 


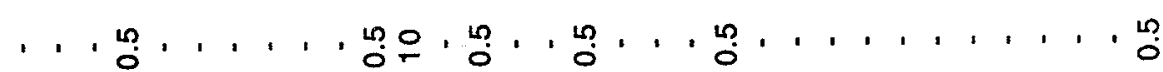

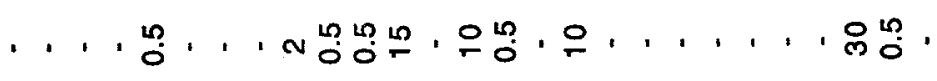

电, , , , , , N

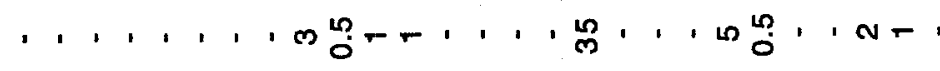

$-$

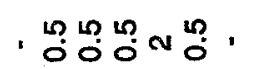

.

, 눙

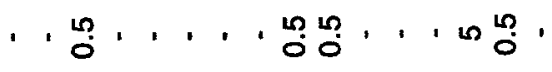

.

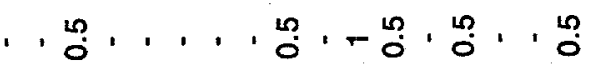

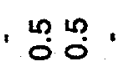

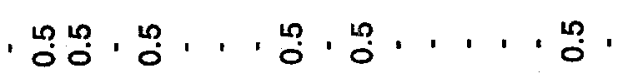

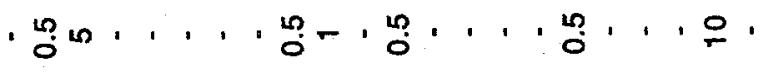

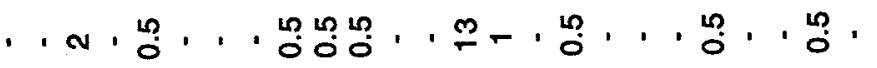

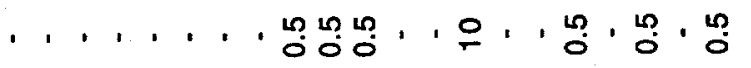

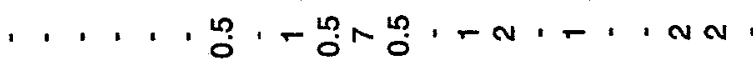

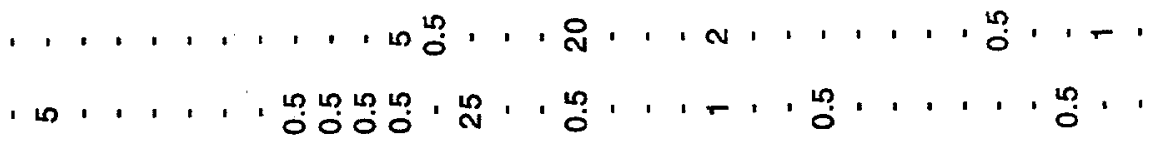

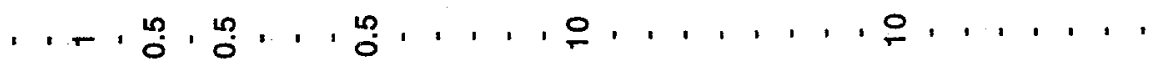

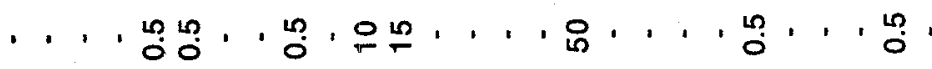

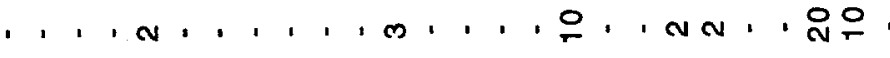

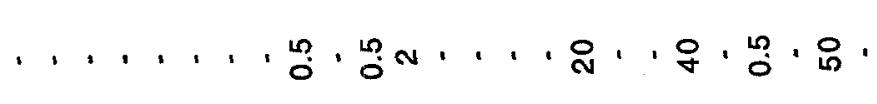

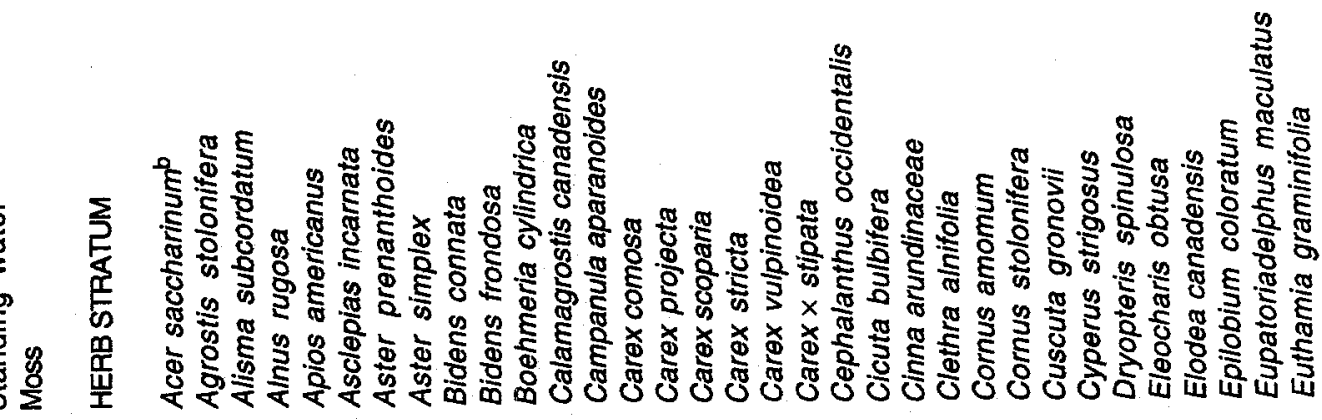

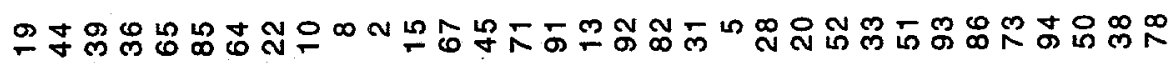









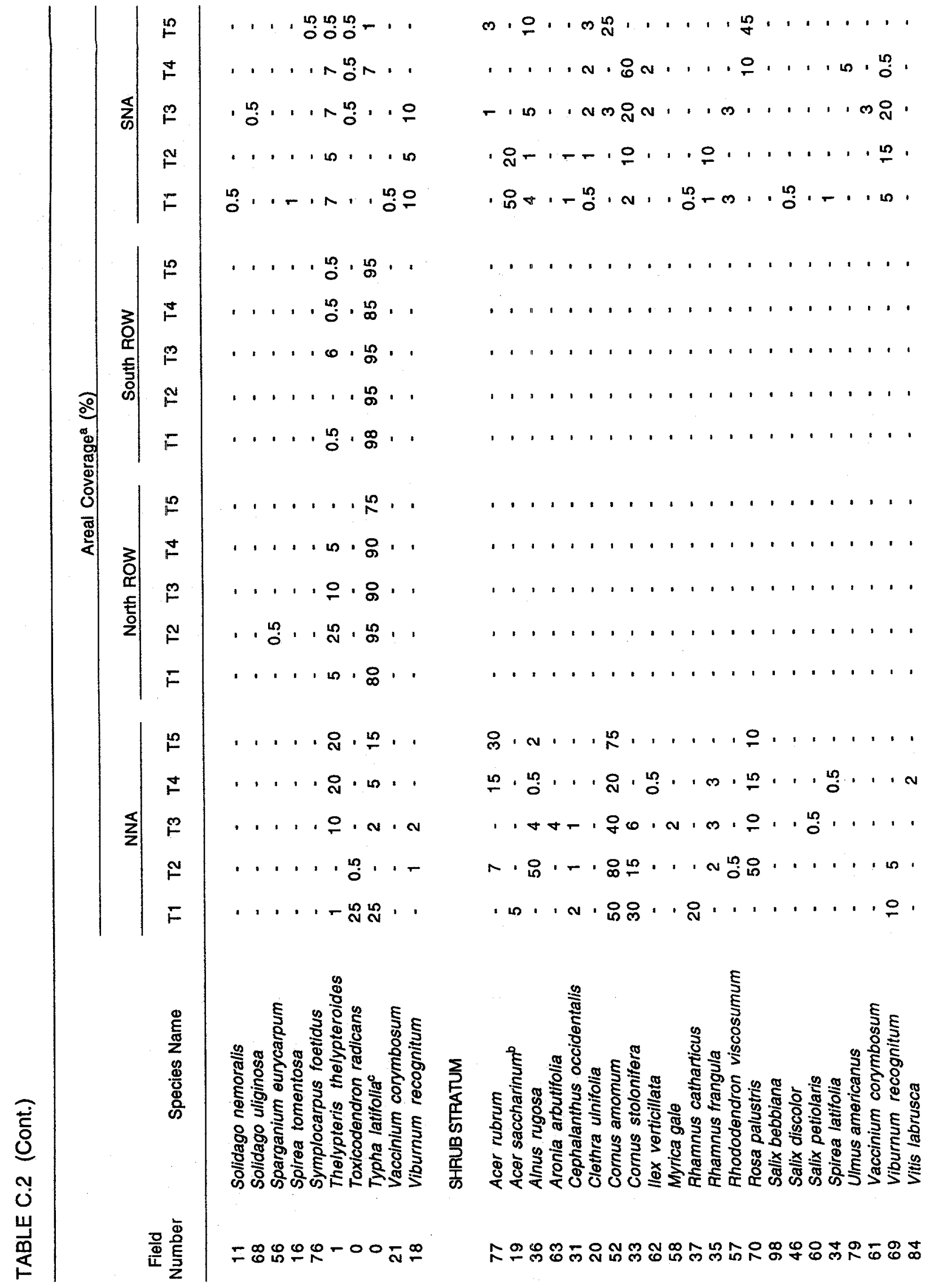




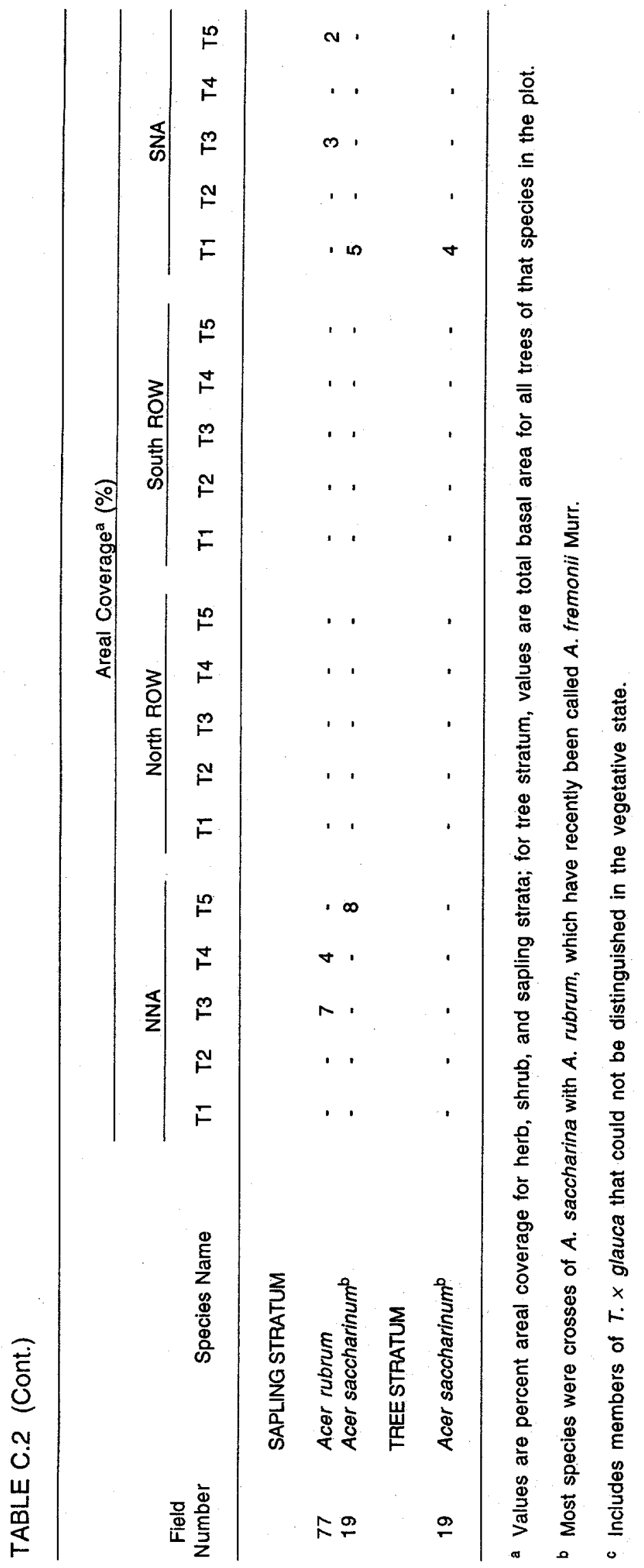


TABLE C.3 Average Percent Coverage, Absolute Frequencies, and Distribution of Species by Stratum for Norris Brook Crossing

\begin{tabular}{|c|c|c|c|c|c|}
\hline \multirow[b]{2}{*}{$\begin{array}{l}\text { Field } \\
\text { Number }\end{array}$} & \multirow[b]{2}{*}{ Species Name } & \multicolumn{4}{|c|}{$\begin{array}{c}\text { Average Percent Coverage/ } \\
\text { Absolute Frequency }\end{array}$} \\
\hline & & NNA & $\begin{array}{l}\text { North } \\
\text { ROW }\end{array}$ & $\begin{array}{l}\text { South } \\
\text { ROW }\end{array}$ & SNA \\
\hline & Standing Water & $86 / 5$ & $100 / 5$ & $100 / 5$ & $83 / 5$ \\
\hline & Moss & $0.0 \%$ & $0.2 / 1$ & 0.010 & $0.0 / 0$ \\
\hline & HERB STRATUM & & & & \\
\hline & Plants occurring in all four are & & & & \\
\hline 65 & Apios americanus & $0.6 / 3$ & $0.1 / 1$ & $0.1 / 1$ & $0.1 / 1$ \\
\hline 10 & Bidens connata & $0.2 / 2$ & $0.5 / 5$ & $0.8 / 4$ & $1.5 / 5$ \\
\hline 2 & Boehmeria cylindrica & $2.4 / 4$ & $1.7 / 4$ & $0.7 / 3$ & $0.9 / 5$ \\
\hline 15 & Calamagrostis canadensis & $4.0 / 3$ & $1.2 / 3$ & $0.4 / 3$ & $5.3 / 4$ \\
\hline 13 & Carex stricta & $19 / 5$ & $4.5 / 5$ & $0.5 / 4$ & $20.1 / 5$ \\
\hline 5 & Cicuta bulbifera & $0.4 / 1$ & $1.2 / 5$ & $3.6 / 5$ & $3.2 / 4$ \\
\hline 12 & Galium trifidum & $0.3 / 3$ & $2.5 / 5$ & $3.4 / 5$ & $2.6 / 5$ \\
\hline 7 & Impatiens capensis & $4.6 / 4$ & $2.8 / 4$ & $6.5 / 5$ & $1.4 / 5$ \\
\hline 0 & Lemna minor $\mathrm{L}$. & $3.2 / 5$ & $24 / 5$ & $19 / 5$ & $69 / 5$ \\
\hline 25 & Lythrum salicaria & $8.0 / 3$ & $35 / 5$ & $36 / 5$ & $7.5 / 5$ \\
\hline 4 & Polygonum arifolium & $0.2 / 2$ & $2.1 / 3$ & $0.4 / 3$ & $5.2 / 4$ \\
\hline 1 & Thelypteris thelypteroides & $10.2 / 4$ & $9.0 / 4$ & $1.5 / 4$ & $5.3 / 5$ \\
\hline \multirow[t]{2}{*}{0} & Typha latifolia & $9.4 / 4$ & $86 / 5$ & $93.6 / 5$ & $1.6 / 2$ \\
\hline & Plants occurring in both NAs an & & & & \\
\hline 26 & Galium obtusum & $0.2 / 2$ & $0.1 / 1$ & $0.0 / 0$ & $1.0 / 1$ \\
\hline 0 & Onoclea sensibilis & $7.0 / 3$ & $1.4 / 1$ & $0.0 \%$ & $1: 3.2 / 3$ \\
\hline 70 & Rosa palustris. & $4.6 / 3$ & $0.2 / 2$ & $0.0 / 0$ & $0.1 / 1$ \\
\hline \multirow[t]{2}{*}{3} & Solanum dulcamara & $35.2 / 5$ & $0.1 / 1$ & $0.0 / 0$ & $6.4 / 5$ \\
\hline & Plants occurring in both NAs or & & & & \\
\hline 36 & Alnus rugosa. & $0.2 / 1$ & $0.0 / 0$ & $0.0 / 0$ & $0.1 / 1$ \\
\hline 28 & Cinna arundinaceae & $0.2 / 2$ & $0.0 / 0$ & $0.0 \%$ & $0.2 / 2$ \\
\hline 33 & Cornus stolonifera & $2.0 / 1$ & $0.0 / 0$ & $0.0 / 0$ & $10.4 / 3$ \\
\hline 51 & Cuscuta gronovii & $2.1 / 2$ & $0.0 / 0$ & $0.0 / 0$ & $0.3 / 2$ \\
\hline 17 & Rhamnus frangula & $1.0 / 1$ & $0.0 / 0$ & $0.0 / 0$ & $1.5 / 3$ \\
\hline 0 & Toxicodendron radicans & $5.1 / 2$ & $0.0 / 0$ & $0.0 / 0$ & $0.3 / 3$ \\
\hline \multirow[t]{2}{*}{18} & Viburnum recognitum & $0.6 / 2$ & $0.0 / 0$ & $0.0 / 0$ & $5.0 / 3$ \\
\hline & Plants occurring in the SNA and & 1e ROW & & & \\
\hline 8 & Bidens frondosa & $0.0 / 0$ & $0.4 / 4$ & $0.3 / 2$ & $0.4 / 4$ \\
\hline 45 & Carex comosa & $0.0 / 0$ & $9.8 / 4$ & $1.2 / 3$ & $2.2 / 3$ \\
\hline 71 & Carex projecta & $0.0 / 0$ & $0.6 / 2$ & $1.1 / 2$ & $0.1 / 1$ \\
\hline 14 & Leersia oryzoides & $0.0 / 0$ & $0.4 / 3$ & $0.3 / 2$ & $0.4 / 1$ \\
\hline 6 & Lycopus uniflorus & $0.0 / 0$ & $0.1 / 1$ & $0.1 / 1$ & $0.5 / 4$ \\
\hline
\end{tabular}




\begin{tabular}{|c|c|c|c|c|c|}
\hline \multirow[b]{2}{*}{$\begin{array}{c}\text { Field } \\
\text { Number }\end{array}$} & \multirow[b]{2}{*}{ Species Name } & \multicolumn{4}{|c|}{$\begin{array}{c}\text { Average Percent Coverage/ } \\
\text { Absolute Frequency }\end{array}$} \\
\hline & & NNA & $\begin{array}{l}\text { North } \\
\text { ROW }\end{array}$ & $\begin{array}{l}\text { South } \\
\text { ROW }\end{array}$ & SNA \\
\hline & Plant occurring in the SNA and & OW & & & \\
\hline \multirow[t]{2}{*}{62} & Ilex verticillata & $0.0 / 0$ & $0.0 / 0$ & $0.1 / 1$ & $0.1 / 1$ \\
\hline & Plant occurring in the SNA and & e ROW & & & \\
\hline \multirow[t]{2}{*}{9} & Scutellaria galericulata & $0.0 / 0$ & $0.1 / 1$ & $0.0 / 0$ & $0.1 / 1$ \\
\hline & Plants occurring in the SNA onl & & & & \\
\hline 19 & Acer saccharinumb & $0.0 / 0$ & $0.0 / 0$ & $0.0 / 0$ & $0.3 / 2$ \\
\hline 22 & Aster simplex & $0.0 / 0$ & $0.0 / 0$ & $0.0 / 0$ & $0.1 / 1$ \\
\hline 20 & Clethra alnifolia & $0.0 / 0$ & $0.0 / 0$ & $0.0 / 0$ & $2.4 / 2$ \\
\hline 86 & Dryopteris spinulosa & $0.0 / 0$ & $0.0 / 0$ & $0.0 / 0$ & $0.1 / 1$ \\
\hline 78 & Euthamia graminifolia & $0.0 / 0$ & $0.0 / 0$ & $0.0 / 0$ & $0.1 / 1$ \\
\hline 29 & Iris versicolor & $0.0 / 0$ & $0.0 / 0$ & $0.0 / 0$ & $0.1 / 1$ \\
\hline 27 & Maianthemum canadense & $0.0 / 0$ & $0.0 / 0$ & $0.0 / 0$ & $0.2 / 2$ \\
\hline 24 & Mentha arvensis & $0.0 / 0$ & $0.0 / 0$ & $0.0 / 0$ & $0.1 / 1$ \\
\hline 58 & Myrica gale & $0.0 / 0$ & $0.0 / 0$ & $0.0 / 0$ & $0.1 / 1$ \\
\hline 81 & Osmunda cinnamomia & $0.0 / 0$ & $0.0 / 0$ & $0.0 / 0$ & $0.1 / 1$ \\
\hline 32 & Osmunda regalis & $0.0 / 0$ & $0.0 / 0$ & $0.0 / 0$ & $0.1 / 1$ \\
\hline 66 & Quercus sp. (seedling) & $0.0 / 0$ & $0.0 / 0$ & $0.0 / 0$ & $0.1 / 1$ \\
\hline 23 & Rubus allegheniensis & $0.0 / 0$ & $0.0 / 0$ & $0.0 / 0$ & $0.1 / 1$ \\
\hline 80 & Solidago gigantea & $0.0 / 0$ & $0.0 / 0$ & $0.0 / 0$ & $0.1 / 1$ \\
\hline 11 & Solidago nemoralis & $0.0 / 0$ & $0.0 / 0$ & $0.0 / 0$ & $0.1 / 1$ \\
\hline 68 & Solidago uliginosa & $0.0 / 0$ & $0.0 / 0$ & $0.0 / 0$ & $0.1 / 1$ \\
\hline 16 & Spirea tomentosa & $0.0 / 0$ & $0.0 / 0$ & $0.0 / 0$ & $0.2 / 1$ \\
\hline 76 & Symplocarpus foetidus & $0.0 / 0$ & $0.0 / 0$ & $0.0 / 0$ & $0.1 / 1$ \\
\hline \multirow[t]{2}{*}{21} & Vaccinium corymbosum & $0.0 / 0$ & $0.0 / 0$ & $0.0 / 0$ & $0.1 / 1$ \\
\hline & Plants occurring in the NNA and & 30W & & & \\
\hline 39 & Alisma subcordatum & $0.2 / 1$ & $0.4 / 1$ & $1.4 / 5$ & $0.0 / 0$ \\
\hline 74 & Ludwegia palustris & $0.1 / 2$ & $3.4 / 2$ & $1.5 / 2$ & $0.0 / 0$ \\
\hline \multirow[t]{2}{*}{49} & Sium suave & $0.5 / 2$ & $0.2 / 2$ & $0.1 / 1$ & $0.0 / 0$ \\
\hline & Plants occurring in the NNA and & he ROW & & & \\
\hline 64 & Aster prenanthoides ${ }^{c}$ & $0.1 / 1$ & $0.1 / 1$ & $0.0 / 0$ & $0.0 / 0$ \\
\hline 31 & Cephalanthus occidentalis & $8.8 / 2$ & $0.4 / 1$ & $0.0 / 0$ & $0.0 / 0$ \\
\hline 52 & Cornus amomum & $14.0 / 2$ & $0.2 / 2$ & $0.0 / 0$ & $0.0 / 0$ \\
\hline
\end{tabular}


TABLE C.3 (Cont.)

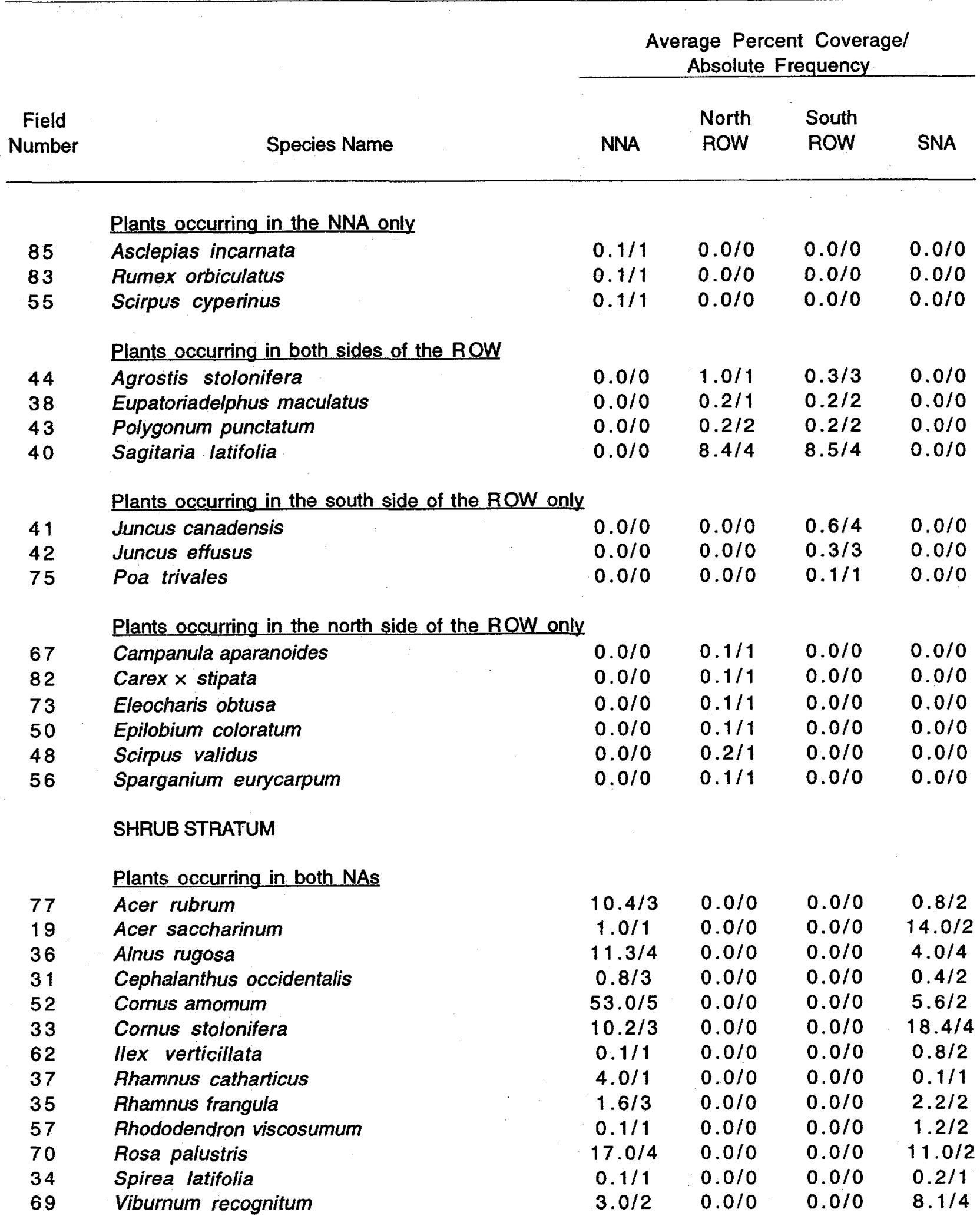




\begin{tabular}{|c|c|c|c|c|c|}
\hline \multirow[b]{2}{*}{$\begin{array}{l}\text { Field } \\
\text { Number }\end{array}$} & \multirow[b]{2}{*}{ Species Name } & \multicolumn{4}{|c|}{$\begin{array}{c}\text { Average Percent Coverage/ } \\
\text { Absolute Frequency }\end{array}$} \\
\hline & & NNA & $\begin{array}{l}\text { North } \\
\text { ROW }\end{array}$ & \multirow[t]{2}{*}{$\begin{array}{l}\text { South } \\
\text { ROW }\end{array}$} & SNA \\
\hline & Plants occurring in SNA only & & & & \\
\hline 20 & Clethra ulnifolia & $0.0 / 0$ & $0.0 / 0$ & $0.0 / 0$ & $1.7 / 5$ \\
\hline 46 & Salix discolor & $0.0 / 0$ & $0.0 / 0$ & $0.0 / 0$ & $0.1 / 1$ \\
\hline 79 & Ulmus americanus & $0.0 / 0$ & $0.0 / 0$ & $0.0 / 0$ & $1.0 / 1$ \\
\hline \multirow[t]{2}{*}{61} & Vaccinium corymbosum & $0.0 / 0$ & 0.010 & $0.0 / 0$ & $0.6 / 1$ \\
\hline & Plants occurring in NNA only & & & & \\
\hline 63 & Aronia arbutifolia & $0.8 / 1$ & $0.0 / 0$ & $0.0 / 0$ & $0.0 / 0$ \\
\hline 58 & Myrica gale & $0.4 / 1$ & $0.0 / 0$ & $0.0 / 0$ & $0.0 / 0$ \\
\hline \multirow[t]{3}{*}{60} & Salix petiolaris & $0.1 / 1$ & $0.0 / 0$ & $0.0 / 0$ & $0.0 / 0$ \\
\hline & SAPLING STRATUM & & & & \\
\hline & Plants occurring in both NAs & & & & \\
\hline 77 & Acer rubrum & $2.2 / 2$ & $0.0 / 0$ & $0.0 / 0$ & $1.0 / 2$ \\
\hline \multirow[t]{3}{*}{19} & Acer saccharinum & $1.6 / 1$ & $0.0 / 0$ & $0.0 / 0$ & $1.0 / 1$ \\
\hline & TREE STRATUM & & & & \\
\hline & Plants occuring in SNA only & & & & \\
\hline \multirow[t]{2}{*}{19} & Acer saccharinum & $0.0 / 0$ & $0.0 / 0$ & $0.0 / 0$ & $0.8 / 1$ \\
\hline & Plants in area but not in plots & & & & \\
\hline 91 & Carex scoparia & & & & \\
\hline 92 & Carex vulpinoidea & & & & \\
\hline 93 & Cyperus strigosus & & & & \\
\hline 94 & Elodea canadensis & & & & \\
\hline 95 & Polygonum hydropiperoides & & & & \\
\hline 96 & Polygonum lapathifolium & & & & \\
\hline 97 & Rorippa palustris & & & & \\
\hline 98 & Salix bebbiana & & & & \\
\hline 99 & Scirpus atrovirens & & & & \\
\hline 84 & Vitis labrusca & & & & \\
\hline
\end{tabular}

a Includes members of $T . \times$ glauca, which could not be distinguished in the vegetative state.

${ }^{b}$ Most specimens were crosses of $A$. saccharina with $A$. rubrum, which have recently been called A. fremonii Murr.

c Note Aster prenanthoides is on the plants of special concern list for Massachusetts. 